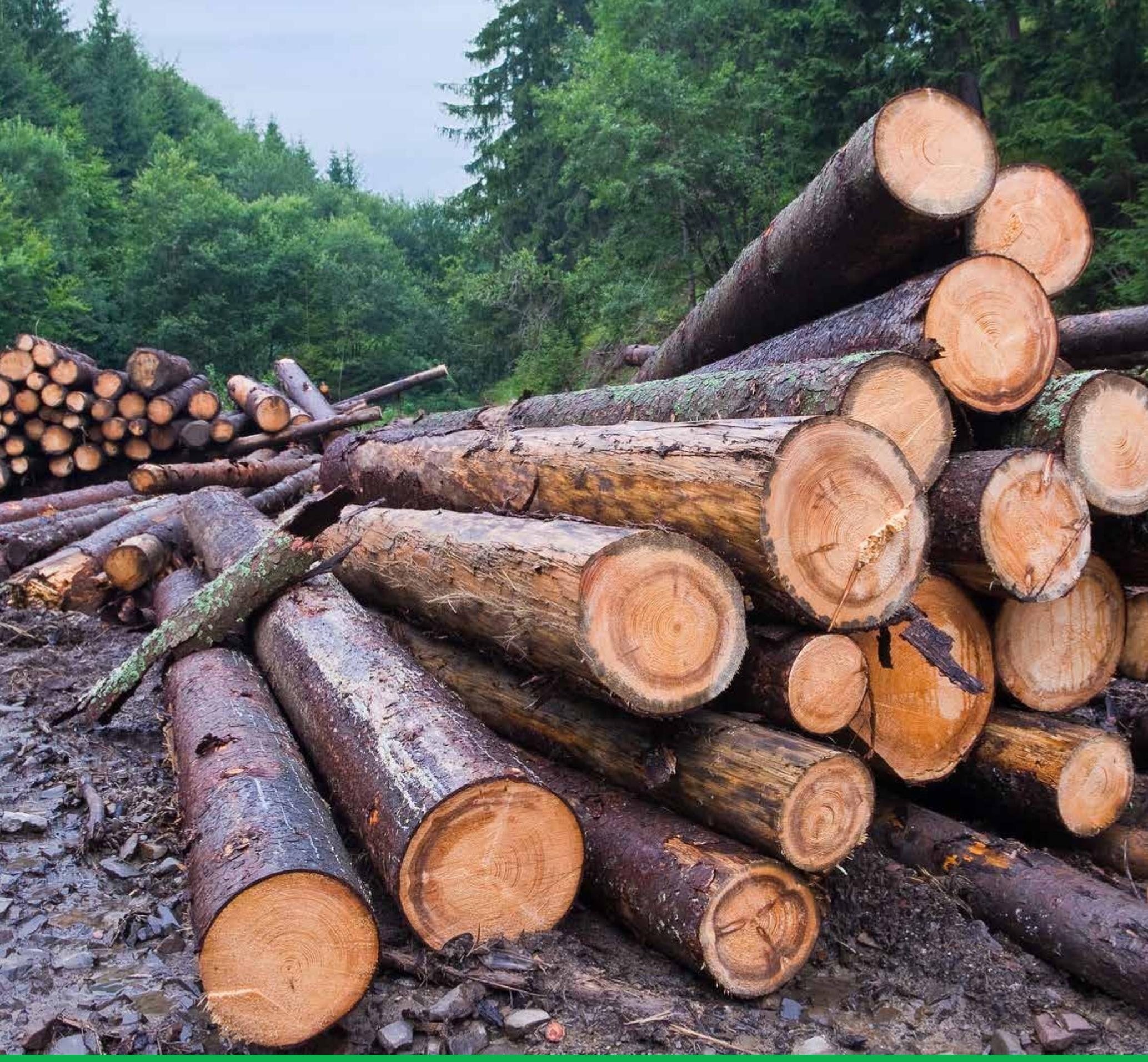

\title{
Bedrijfsuitkomsten in de Nederlandse particuliere bosbouw over 2017
}

H.J. Silvis en M.J. Voskuilen 



\section{Bedrijfsuitkomsten in de Nederlandse particuliere bosbouw over 2017}

H.J. Silvis en M.J. Voskuilen

Dit onderzoek is uitgevoerd door Wageningen Economic Research in opdracht van en gefinancierd door het ministerie van Landbouw, Natuur en Voedselkwaliteit, in het kader van het onderzoeksthema 'Economische informatievoorziening' (projectnummer WOT-06-001-007).

Wageningen Economic Research

Wageningen, mei 2019

RAPPORT

2019-048

ISBN 978-94-6343-980-0 
Silvis, H.J. en M.J. Voskuilen, 2019. Bedrijfsuitkomsten in de Nederlandse particuliere bosbouw over 2017. Wageningen, Wageningen Economic Research, Rapport 2019-048. 50 blz.; 12 fig.; 20 tab.; 5 ref.

Dit rapport biedt een overzicht van de bedrijfsresultaten van particuliere bosbedrijven in 2017. Hierbij gaat het om particuliere boseigenaren met meer dan 5 ha bos, met uitzondering van de particuliere natuurbeschermingsorganisaties. De Nederlandse particuliere bosbedrijven hebben gemiddeld in 2017 een negatief resultaat geboekt van -44 euro per ha bos. Dit resultaat is lager dan in de voorafgaande jaren: -8 euro in 2016 en 14 euro in 2015. De daling is het gevolg van hogere arbeidskosten en iets lagere houtopbrengsten.

Trefwoorden: bosbouw, bedrijfsresultaten, opbrengsten, kosten, bedrijfsgrootte, regio

Dit rapport is gratis te downloaden op https://doi.org/10.18174/477327 of op www. wur. nl/economicresearch (onder Wageningen Economic Research publicaties).

(C) 2019 Wageningen Economic Research

Postbus 29703, 2502 LS Den Haag, T 07033583 30, E communications.ssg@wur.nl, www.wur. nl/economic-research. Wageningen Economic Research is onderdeel van Wageningen University \& Research.

\section{(cc) BY-NC}

Dit werk valt onder een Creative Commons Naamsvermelding-Niet Commercieel 4.0 Internationaallicentie.

(C) Wageningen Economic Research, onderdeel van Stichting Wageningen Research, 2019

De gebruiker mag het werk kopiëren, verspreiden en doorgeven en afgeleide werken maken. Materiaal van derden waarvan in het werk gebruik is gemaakt en waarop intellectuele eigendomsrechten berusten, mogen niet zonder voorafgaande toestemming van derden gebruikt worden. De gebruiker dient bij het werk de door de maker of de licentiegever aangegeven naam te vermelden, maar niet zodanig dat de indruk gewekt wordt dat zij daarmee instemmen met het werk van de gebruiker of het gebruik van het werk. De gebruiker mag het werk niet voor commerciële doeleinden gebruiken.

Wageningen Economic Research aanvaardt geen aansprakelijkheid voor eventuele schade voortvloeiend uit het gebruik van de resultaten van dit onderzoek of de toepassing van de adviezen.

Wageningen Economic Research is ISO 9001:2008 gecertificeerd.

Wageningen Economic Research Rapport 2019-048 | Projectcode 2282200453

Foto omslag: Shutterstock 


\section{Inhoud}

Woord vooraf $\quad 5$

$\begin{array}{ll}\text { Samenvatting } & 6\end{array}$

S.1 Belangrijkste uitkomsten $\quad 6$

$\begin{array}{lll}\text { S.2 Overige uitkomsten } & 7\end{array}$

$\begin{array}{ll}\text { S.3 Methode } & 7\end{array}$

1

$\begin{array}{ll}\text { Inleiding } & \mathbf{8}\end{array}$

1.1 Doel en opzet monitor particuliere bosbouw $\quad 8$

$\begin{array}{llr}1.2 & \text { Particuliere bosbedrijven } & 8\end{array}$

$\begin{array}{lll}1.3 & \text { Deelnemers aan het Informatienet } & 10\end{array}$

1.4 Opbouw en interpretatie van het bedrijfsresultaat $\quad 10$

2

$\begin{array}{ll}\text { Resultaten van alle bedrijven } & 12\end{array}$

$\begin{array}{lll}2.1 & \text { Bedrijfsresultaten } & 12\end{array}$

2.2 Opbrengsten 12

2.3 Kosten 14

$\begin{array}{ll}2.4 & \text { Spreiding in resultaten }\end{array}$

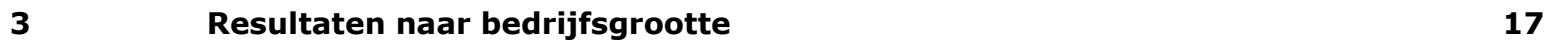

3.1 Resultaten grotere bedrijven (minstens 50 ha bos) 17

3.2 Resultaten naar bedrijfsgrootte 18

3.3 Opbrengsten naar bedrijfsgrootte 19

$\begin{array}{lll}3.4 & \text { Kosten naar bedrijfsgrootte } & 19\end{array}$

$\begin{array}{lll}3.5 & \text { Kostenplaatsen en bedrijfsgrootte } & 20\end{array}$

$4 \quad$ Resultaten naar regio $\quad 21$

$\begin{array}{lll}4.1 & \text { Bedrijfsresultaten naar regio } & 21\end{array}$

$\begin{array}{lll}4.2 & \text { Opbrengsten naar regio } & 21\end{array}$

$\begin{array}{lll}4.3 & \text { Kosten naar regio } & 22\end{array}$

$5 \quad$ Resultaten in historisch perspectief $\quad 23$

5.1 Bedrijfsresultaten op lange termijn 23

5.2 Kosten en opbrengsten van alle bedrijven 23

5.3 Kosten en opbrengsten van grotere bedrijven $\quad 24$

5.4 Houtprijzen en oogstvolume $\quad 26$

$\begin{array}{ll}\text { Literatuur en websites } & \mathbf{2 8}\end{array}$

Bijlage 1 Begrippen $\quad 29$

$\begin{array}{lll}\text { Bijlage } 2 & \text { Tabellen } & 33\end{array}$ 



\section{Woord vooraf}

In opdracht van het ministerie van Landbouw, Natuur en Voedselkwaliteit geeft dit rapport een overzicht van de bedrijfsresultaten, opbrengsten en kosten van particuliere bosbedrijven in 2017. Deze worden afgezet tegen de resultaten in de voorafgaande jaren. Na een periode met gemiddeld positieve bedrijfsresultaten, zijn 2016 en 2017 afgesloten met negatieve resultaten als gevolg van hogere arbeidskosten en iets lagere houtopbrengsten.

Namens de opdrachtgever is ir. Peter van der Knaap, beleidsmedewerker natuur en biodiversiteit, opgetreden als contactpersoon.

Behalve aan hem is ook veel dank verschuldigd aan de eigenaren en beheerders van particuliere bosbezittingen die, door het ter beschikking stellen van bedrijfsgegevens, deze publicatie mogelijk hebben gemaakt. De dataverzameling is verzorgd door Jeroen Bremer, René van den Broek, Henk Nuijen, Gunther Tap en Roel van der Velde.

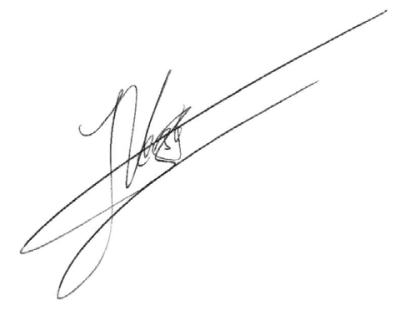

Prof.dr.ir. J.G.A.J. (Jack) van der Vorst Algemeen Directeur Social Sciences Group (SSG)

Wageningen University \& Research 


\section{Samenvatting}

\section{S.1 Belangrijkste uitkomsten}

De Nederlandse particuliere bosbedrijven hebben gemiddeld in 2017 een resultaat geboekt van -44 euro per ha bos. Dit resultaat is fors lager dan in de twee voorafgaande jaren: -8 euro in 2016 en 14 euro in 2015. De gemiddelde houtopbrengsten zijn gedaald en de arbeidskosten gestegen.

Tabel S.1 Resultaten (euro per ha bos) van particuliere bosbedrijven, 2013-2017

\begin{tabular}{lrrrrr} 
& 2013 & 2014 & 2015 & 2016 & 2017 \\
\hline Opbrengsten & 305 & 312 & 293 & 281 & 271 \\
\hline Kosten & 281 & 273 & 279 & 289 & 315 \\
\hline Bedrijfsresultaat & 24 & 39 & 14 & -8 & -44 \\
\hline Opbrengsten/kosten (\%) & 109 & 114 & 105 & 97 & 86 \\
\hline Inkomen uit het bosbedrijf & 67 & 80 & 59 & 39 & 9 \\
\hline
\end{tabular}

Bron: Informatienet, Wageningen Economic Research.

Het gemiddelde inkomen uit het bosbedrijf - het bedrijfsresultaat plus de berekende arbeidsvergoeding (in hoofdzaak van de eigenaar) - kwam in 2017 uit op 9 euro per ha, tegenover 39 euro per ha in 2016 en 59 euro per ha in 2015.

De fluctuaties in de bedrijfsresultaten zijn door de jaren heen over het algemeen vrij groot, met negatieve en positieve uitschieters. Gedurende veel jaren zijn negatieve resultaten geboekt. Daarentegen zijn de resultaten in de periode 2010-2015 opvallend positief geweest (figuur S.1).

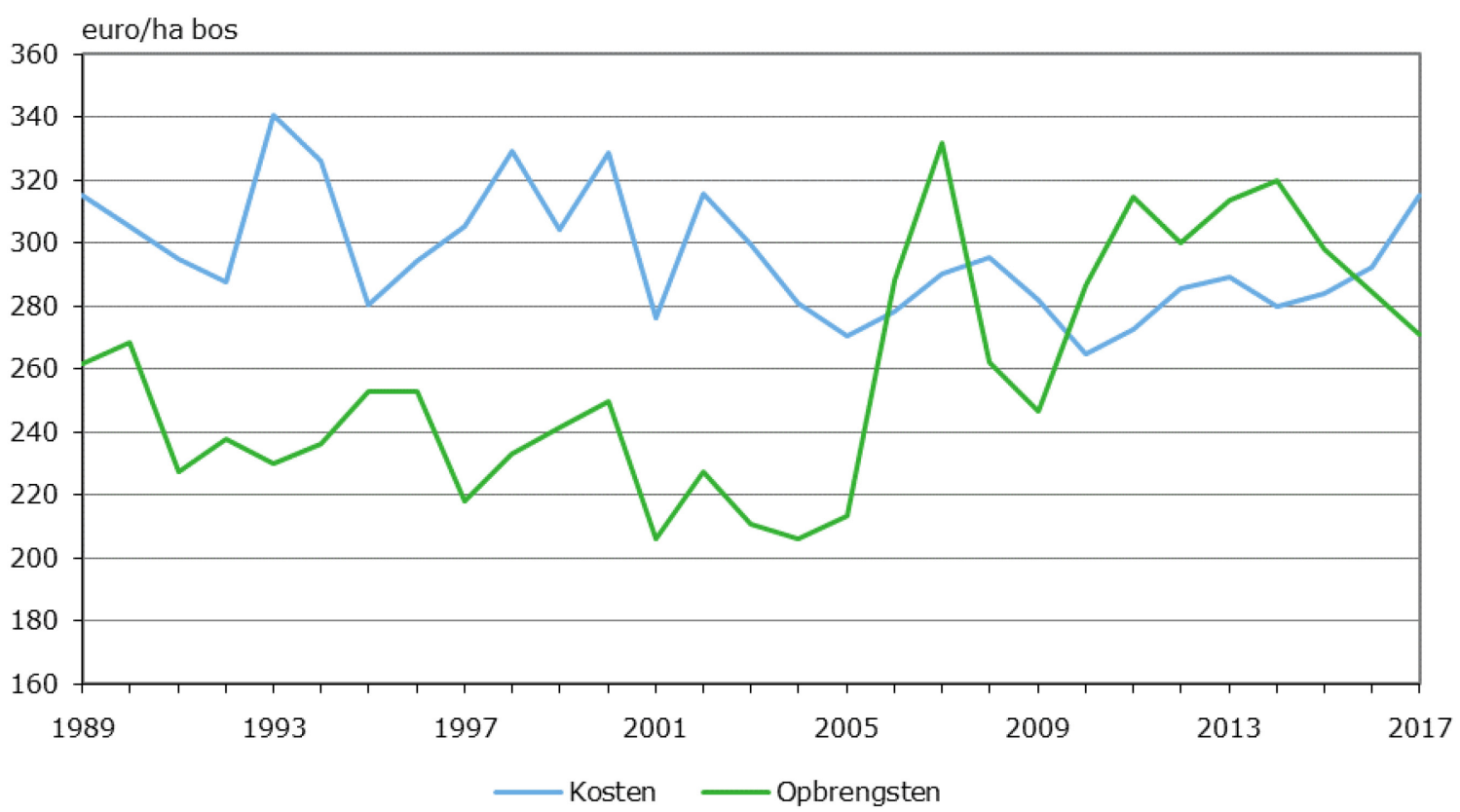

Figuur S.1 Reële kosten en opbrengsten per ha bos (in euro's van 2017) op particuliere bosbedrijven, 1989-2017

Bron: Informatienet, Wageningen Economic Research. 


\section{S.2 Overige uitkomsten}

De resultaten van de particuliere bosbedrijven lopen sterk uiteen. In 2017 had $42 \%$ van de bedrijven een bedrijfsresultaat van minder dan -100 euro per ha, en 15\% een resultaat van meer dan 100 euro per ha. In de periode 2015-2017 heeft gemiddeld 40\% van de bedrijven een positief resultaat behaald. De bedrijven die uit de rode cijfers bleven, beheerden gemiddeld $48 \%$ van het bosareaal (hoofdstuk 2).

De exploitatie van het bosbeheer is in de periode 2013-2017 gemiddeld genomen kostendekkend geweest: een plus van 5 euro per ha bos. Dat gold voor alle groepen bedrijven, behalve voor de kleinere bedrijven ( 5 tot 25 ha en 25 tot 50 ha). Over het algemeen lopen de bedrijfsresultaten op bij een toenemende bedrijfsomvang (ha bos). In de groepen 5-25 ha en 25-50 ha heeft gemiddeld 40\% in de periode 2013-2017 een positief bedrijfsresultaat geboekt; voor de daarop volgende groepen loopt het aandeel met een positief resultaat op van 53\% tot 59\% (hoofdstuk 3).

De bosbedrijven in de drie onderscheiden regio's (Noordoost, Zuid en Centrum) verschillen qua bedrijfsvoering en bedrijfsresultaten sterk van elkaar. In het Centrum liggen de opbrengsten en kosten van het bosbeheer relatief hoog, zowel door een hogere houtoogst als door het intensievere gebruik van het bos voor andere activiteiten, zoals recreatie. In deze regio sloten de particuliere boseigenaren 2017 af met een gemiddeld resultaat onder -100 euro per ha bos. Particuliere boseigenaren in de regio's Noordoost en Zuid hebben in 2017 ook een negatief bedrijfsresultaat geboekt: gemiddeld -20 euro -11 euro per ha bos (hoofdstuk 4).

\section{S.3 Methode}

De jaarlijkse publicatie van Wageningen Economic Research over de bedrijfsuitkomsten in de Nederlandse particuliere bosbouw verschijnt in opdracht van het ministerie van Landbouw, Natuur en Voedselkwaliteit. De publicatie verschaft informatie over de bedrijfsresultaten (in euro per ha bos) van particuliere bedrijven met meer dan 5 ha bos. Hierbij gaat het om particuliere boseigenaren, met uitzondering van de natuurbeschermingsorganisaties. De resultaten over 2017 zijn gebaseerd op de deeladministraties van 147 bedrijven uit het Informatienet van Wageningen Economic Research (zie hoofdstuk 1). De administraties hebben alleen betrekking op de resultaten van het bosbedrijf. Met de vergelijking van de jaarlijkse uitkomsten moet voorzichtig worden omgegaan, omdat de bedrijfsvoering in het bos op de lange termijn is gericht en de werkzaamheden (beheer, verjonging, onderhoud, vellingen) niet steeds gelijkmatig over de jaren gespreid zijn. 


\section{$1 \quad$ Inleiding}

\section{$1.1 \quad$ Doel en opzet monitor particuliere bosbouw}

Deze jaarlijkse publicatie van de bedrijfsuitkomsten in de Nederlandse particuliere bosbouw geeft informatie over bedrijfsresultaten, opbrengsten en kosten van particuliere bedrijven met meer dan 5 ha bos. Dit gebeurt onder meer ten behoeve van het beleid van de overheid (nationaal en regionaal), de Vereniging van Bos- en Natuurterreineigenaren (VBNE) en de eigenaren en beheerders van particuliere bosbedrijven. De publicatie is gebaseerd op gegevens van circa 150 particuliere boseigenaren.

De volgende hoofdstukken behandelen de gemiddelde bedrijfsresultaten van alle bedrijven (hoofdstuk 2), de bedrijfsresultaten naar bedrijfsgrootte (hoofdstuk 3) en de bedrijfsresultaten naar regio (hoofdstuk 4). In het afsluitende hoofdstuk 5 worden de langetermijnontwikkelingen van de particuliere bosbouw belicht.

In het vervolg van dit hoofdstuk wordt ingegaan op de omvang en samenstelling van de groep particuliere bosbedrijven (paragraaf 1.2 ) en de deelnemers aan het Informatienet particuliere bosbedrijven van Wageningen Economic Research (paragraaf 1.3). Ten slotte worden de economische begrippen van de publicatie toegelicht (paragraaf 1.4). Bijlage 1 bevat een uitgebreider overzicht van de begrippen in dit rapport.

\subsection{Particuliere bosbedrijven}

Alle eigenaren van minimaal 5 ha bos waren vroeger verplicht geregistreerd bij het Bosschap - het inmiddels opgeheven bedrijfschap voor bos en natuur. Daarbij is onderscheid gemaakt tussen bosbezit in publieke hand, zoals de boseigendommen van het Rijk (waaronder Staatsbosbeheer, Domeinen, Defensie), provincies, waterschappen en gemeenten, en bosbezit in private handen.

De populatie van het Informatienet particuliere bosbedrijven van Wageningen Economic Research wordt gevormd door de private boseigenaren, met uitzondering van de natuurbeschermingsorganisaties. Volgens de meest recente data uit 2012 zijn er 1.520 van dergelijke bedrijven in Nederland, met een bosbezit van in totaal bijna 63.000 ha (tabel 1.1).

Tabel 1.1 Particuliere bosbezittingen naar oppervlakte en regio, 2012

\begin{tabular}{|c|c|c|}
\hline & Aantal bedrijven & Bosareaal (ha) \\
\hline \multicolumn{3}{|l|}{ Oppervlakte } \\
\hline 5 tot 25 ha & 904 & 10.328 \\
\hline 50 tot 100 ha & 131 & 8.850 \\
\hline 100 tot 250 ha & 70 & 10.315 \\
\hline \multicolumn{3}{|l|}{ Regio } \\
\hline Noordoost & 637 & 25.060 \\
\hline Centrum & 370 & 18.645 \\
\hline Zuid & 357 & 15.052 \\
\hline Totaal & 1.520 & 62.754 \\
\hline
\end{tabular}

Bron: Bosschap, bewerking Wageningen Economic Research. 
Dit areaal is ongeveer $17 \%$ van het bosareaal in Nederland, dat volgens de laatste nationale bosinventarisatie (Schelhaas et al., 2014) 373.480 ha omvat. Hiervan is $48,2 \%$ publiek bezit en $19,4 \%$ in handen van natuurbeschermingsorganisaties (inclusief Natuurmonumenten). Het resterende private areaal is ruim 120.000 ha. Dit is georganiseerd in verschillende rechtsvormen: bedrijf, landgoed, overig particulier georganiseerd, privé. In combinatie met de registratie van het Bosschap (tabel 1.1) volgt hieruit dat bijna 59.000 ha bos in handen is van particulieren met minder dan 5 ha bos.

Bij de opzet van het Informatienet is de populatie ingedeeld naar omvang van het bosbezit en de regionale ligging van de bedrijven, twee belangrijke kenmerken voor het onderzoek naar de bedrijfsuitkomsten. Van 1975 tot 1989 bestond de populatie uit bedrijven met meer dan 50 ha bos; in 1989 is de ondergrens verlaagd naar 5 ha (ondergrens van het register van het Bosschap). Dit is gedaan omdat het toenmalige ministerie van LNV en het Bosschap inzicht wilden verkrijgen in de resultaten van alle geregistreerde bedrijven. De bedrijven zijn ingedeeld in vijf oppervlakteklassen (zie tabel 1.2).

De tweede indeling - regionale ligging van de particuliere bosbedrijven - is gebaseerd op de Derde Nederlandse Bosstatistiek. De daarin voorkomende acht gebieden zijn samengevoegd tot vier regio's (figuur 1.1). Deze indeling is vanaf 1975 gelijk gebleven. De regio's zijn:

- Noordoost: ten oosten en ten noorden van de IJssel, met uitzondering van de noordelijke klei- en laagveengebieden

- Centrum: Veluwe, Utrechtse Heuvelrug en Gooi

- Zuid: Noord-Brabant en Limburg, met uitzondering van het rivierengebied

- Overig Nederland.

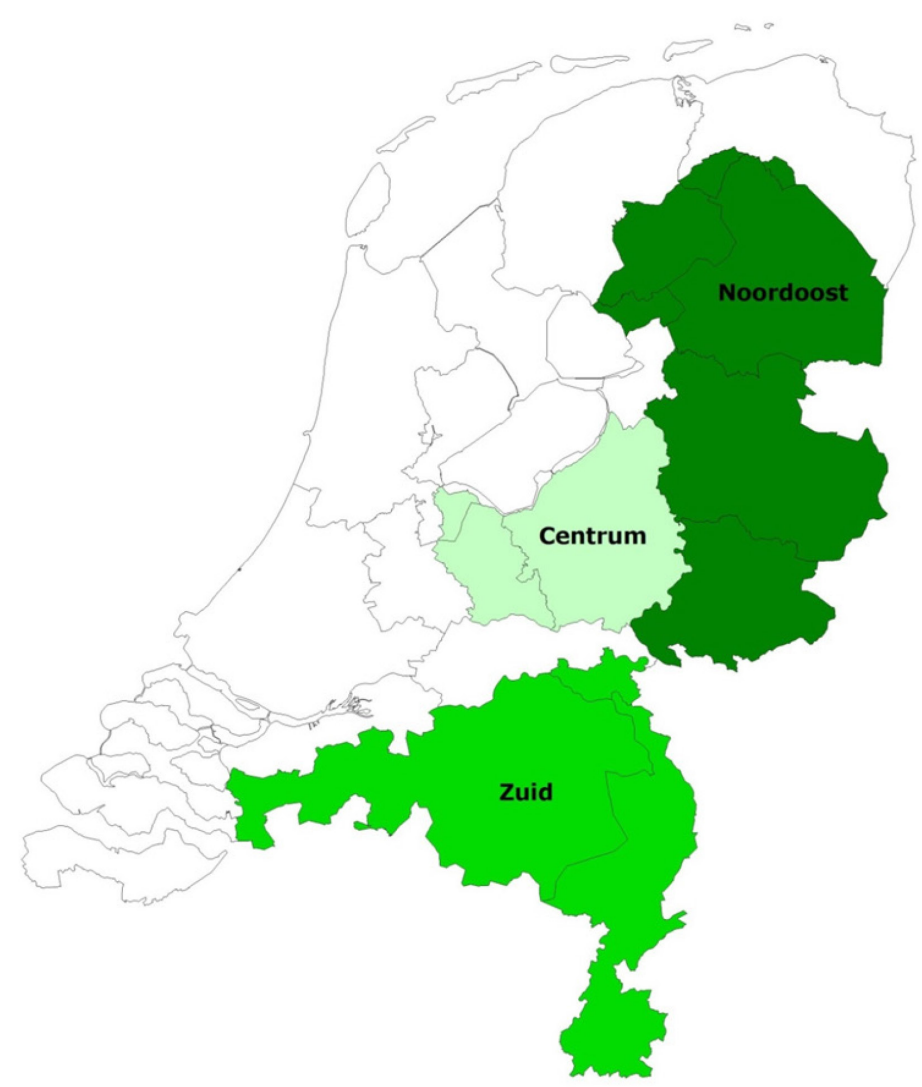

Figuur 1.1 Regio-indeling (gebaseerd op de Derde Nederlandse Bosstatistiek van het CBS) 
Uit de weinig bosrijke regio 'Overig Nederland' is geen steekproef getrokken, zodat deze in het periodieke rapport buiten beschouwing blijft. Ook in de uitkomsten per grootteklasse en voor alle bedrijven zijn de bedrijven uit Overig Nederland niet opgenomen. Hiermee komt de uiteindelijke doelpopulatie van het Informatienet uit op 1.364 particuliere bosbedrijven met een areaal bos van 58.757 ha in 2012 (tabel 1.1).

\subsection{Deelnemers aan het Informatienet}

De deelnemers aan het Informatienet zijn gekozen met behulp van een steekproef uit de hiervoor genoemde doelpopulatie. Daarvoor is de populatie eerst ingedeeld in subgroepen (ook wel aangeduid met cellen of strata) op basis van de grootte van het bosbezit en de ligging. In totaal worden vijftien subgroepen onderscheiden, op basis van de combinatie van vijf oppervlakteklassen en drie regio's.

Tabel 1.2 Steekproefdichtheid naar oppervlakte en regio, 2017

\begin{tabular}{|c|c|c|c|}
\hline & $\begin{array}{l}\text { Aantal steek- } \\
\text { proefbedrijven }\end{array}$ & $\begin{array}{r}\text { Steekproefbedrijven } \\
\text { in } \% \text { van de totale } \\
\text { doelpopulatie }\end{array}$ & $\begin{array}{l}\text { Steekproef- } \\
\text { oppervlakte in \% van } \\
\text { de totale oppervlakte }\end{array}$ \\
\hline 5 tot 25 ha & 42 & 4,6 & 5,1 \\
\hline 25 tot 50 ha & 25 & 11,4 & 12,8 \\
\hline 100 tot 250 ha & 30 & 41,4 & 42,4 \\
\hline 250 ha en meer & 23 & 57,5 & 64,7 \\
\hline \multicolumn{4}{|l|}{ Regio } \\
\hline Noordoost & 58 & 9,1 & 36,8 \\
\hline
\end{tabular}

Bron: Wageningen Economic Research.

Over 2017 zijn de gegevens verzameld van 147 deelnemers ('steekproefbedrijven'), ofwel 11\% van het aantal bedrijven in de doelpopulatie (tabel 1.2). De steekproefbedrijven zijn samen goed voor $37 \%$ van de totale bosoppervlakte van de doelpopulatie.

\subsection{Opbouw en interpretatie van het bedrijfsresultaat}

Van de bedrijven in de steekproef worden zogenaamde deeladministraties bijgehouden. Dat wil zeggen dat alleen opbrengsten en kosten die te maken hebben met het bosbedrijf worden geregistreerd.

De bedrijfsuitkomsten in de particuliere bosbouw worden beschreven aan de hand van bedrijfsresultaat, rentabiliteit, inkomen, opbrengsten en kosten uit het bosbedrijf:

- Het bedrijfsresultaat is het saldo van opbrengsten en kosten, en geeft aan of de bosbouwactiviteiten bedrijfseconomisch rendabel zijn, met andere woorden, in hoeverre de gangbare beloningsaanspraken van de productiefactoren worden gehonoreerd. Overigens zijn geen rentekosten berekend over het in grond en houtopstand geïnvesteerde vermogen.

- De rentabiliteit wordt uitgedrukt in de verhouding tussen opbrengsten en kosten (in procenten). Als deze verhouding onder de $100 \%$ ligt, blijft het resultaat achter bij de gangbare beloningsaanspraken van de productiefactoren. 
- Het inkomen uit het bosbedrijf wordt berekend door het bedrijfsresultaat te vermeerderen met de berekende arbeidskosten van de eigenaar en de overige berekende lonen. Het inkomen uit het bosbedrijf geeft weer wat de beloning van de eigenaar is voor risico, management en arbeid.

- De opbrengsten bestaan uit de opbrengsten van hout, jacht en recreatie en dergelijke, en subsidies. Verhuurt een eigenaar de jacht niet, maar jaagt hij zelf, dan worden daar (normatief) opbrengsten voor in rekening gebracht.

- De kosten bestaan uit arbeidskosten, rente, afschrijving en overige kosten (zoals heffingen, verzekeringen, plantsoen en zaad, brandstoffen enzovoort). Ook worden (normatief) kosten in rekening gebracht voor de door de ondernemer en zijn gezin ingebrachte productiefactoren. Over het in grond en houtopstanden geïnvesteerde vermogen worden echter geen rentekosten berekend. De kosten zijn onder meer ingedeeld naar kostensoorten en kostenplaatsen

(activiteiten/maatregelen), zoals bosverjonging, bosonderhoud en houtoogst.

Voor vergelijkingen in de tijd zijn de nominale bedragen in enkele gevallen (hoofdstuk 5) omgerekend naar reële bedragen met behulp van de prijsmutatie van het bruto binnenlands product. Als dat gebeurd is, wordt het vermeld. In alle andere gevallen zijn de bedragen nominaal. 


\section{Resultaten van alle bedrijven}

\section{$2.1 \quad$ Bedrijfsresultaten}

Gemiddelde bedrijfsresultaten negatief

De Nederlandse particuliere bosbouw heeft 2017 afgesloten met een negatief bedrijfsresultaat van gemiddeld 44 euro per ha bos (tabel 2.1). Dat is een behoorlijke teruggang ten opzichte van voorgaande jaren (2013-2016) waarin gemiddeld een positief resultaat van 17 euro per jaar is gerealiseerd. Het veel lagere resultaat in 2017 is het gevolg van hogere kosten en lagere opbrengsten. De opbrengsten-kostenverhouding is uitgekomen op $86 \%$, tegen gemiddeld $106 \%$ in de jaren 2013 2016.

Tabel 2.1 Resultaten (euro per ha bos) van particuliere bosbedrijven, 2013-2017

\begin{tabular}{lrrrrr} 
& 2013 & 2014 & 2015 & 2016 & 281 \\
Opbrengsten & 305 & 312 & 293 & 271 \\
\hline Kosten & 281 & 273 & 279 & 289 & -8 \\
\hline Bedrijfsresultaat & 24 & 39 & 14 & -44 \\
\hline Opbrengsten/kosten (\%) & 109 & 114 & 105 & 97 & 36 \\
\hline Inkomen uit het bosbedrijf & 67 & 80 & 59 & 39
\end{tabular}

Bron: Informatienet, Wageningen Economic Research.

Het inkomen uit het bosbedrijf is in 2017 uitgekomen op 9 euro per ha per bos (tabel 2.1). In de jaren 2013-2016 was het inkomen uit bedrijf gemiddeld 61 euro per ha.

\subsection{Opbrengsten}

Gemiddelde opbrengsten verminderd

De gemiddelde opbrengsten voor alle particuliere bosbedrijven zijn in 2017 uitgekomen op 271 euro per ha bos (tabel 2.2). Dat is $10 \%$ onder het gemiddelde over de jaren 2013-2016. In vergelijking met die periode is de houtopbrengst met $9 \%$ gedaald, van gemiddeld 140 euro tot 112 euro per ha bos. In 2017 bedroegen de houtopbrengsten $41 \%$ van de totale opbrengsten, tegen gemiddeld $47 \%$ in de periode 2013-2016. Dankzij een stijging van de overige subsidies, liggen de totale subsidies in 2017 iets hoger dan het gemiddelde in de jaren 2013-2016 (95 tegen 91 euro per ha bos). De omvang van de overige opbrengstenposten (jachthuur, recreatie en overig) is vrij stabiel.

Tabel 2.2 Opbrengsten (euro per ha bos) van particuliere bosbedrijven, 2013-2017

\begin{tabular}{|c|c|c|c|c|c|}
\hline & 2013 & 2014 & 2015 & 2016 & 2017 \\
\hline Hout & 149 & 149 & 137 & 123 & 112 \\
\hline w.o. Op stam & 133 & 132 & 120 & 101 & 89 \\
\hline Beheersubsidie & 81 & 74 & 72 & 73 & 73 \\
\hline Overige subsidies & 17 & 24 & 9 & 15 & 22 \\
\hline Recreatie & 29 & 29 & 32 & 32 & 30 \\
\hline Overig & 16 & 22 & 28 & 23 & 21 \\
\hline Totaal & 305 & 312 & 293 & 281 & 271 \\
\hline
\end{tabular}

Bron: Informatienet, Wageningen Economic Research. 


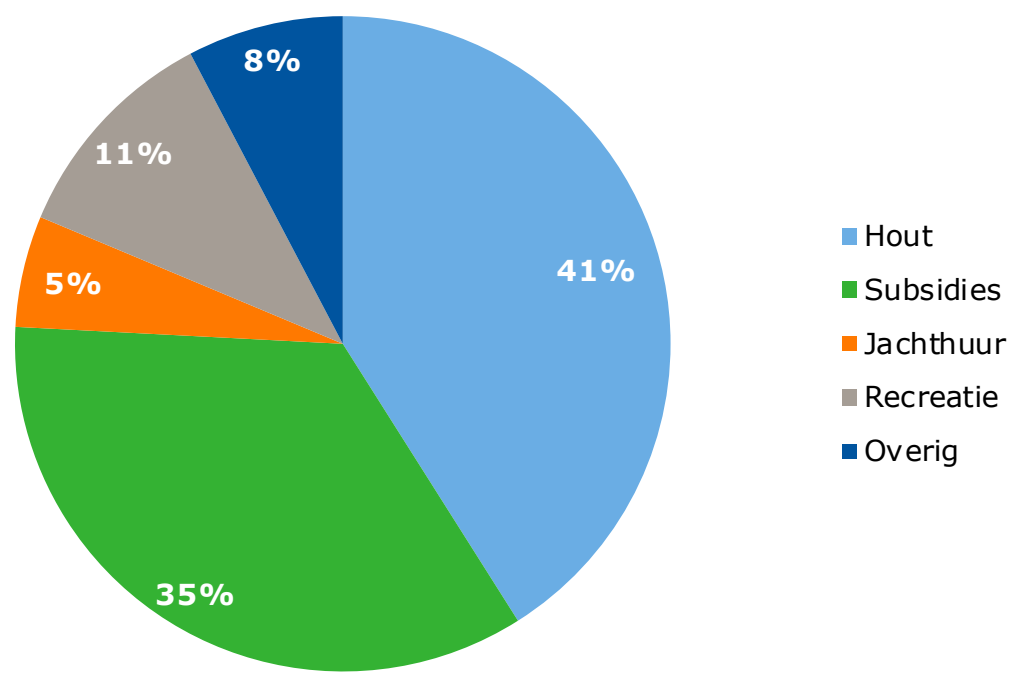

Figuur 2.1 Samenstelling (\%) van de opbrengsten van particuliere bosbedrijven, 2017 Bron: Informatienet, Wageningen Economic Research.

\section{Houtopbrengsten omlaag}

In 2017 is de gemiddelde houtprijs gedaald tot iets minder dan 38 euro per $\mathrm{m}^{3}$ (tabel 2.3). De gemiddelde gewogen houtprijs bereikte in 2016 een piek met 41 euro per $\mathrm{m}^{3}$. In vergelijking met het gemiddelde prijsniveau in 2013-2015 is de prijs in 2017 met $2 \%$ verlaagd.

Tabel 2.3 Opbrengstprijzen (euro per $\mathrm{m}^{3}$ ) van verkocht hout naar verkoopwijze, 2013-2017

\begin{tabular}{llllll} 
& 2013 & 2014 & 2015 & 2016 & 3017 \\
Op stam & 37,57 & 37,96 & 38,19 & 39,63 & 36,19 \\
\hline Geveld & 40,35 & 61,76 & 54,78 & 62,48 & 59,47 \\
\hline Totaal & 37,75 & 38,91 & 38,93 & 41,09 & 37,84 \\
\hline
\end{tabular}

Bron: Informatienet, Wageningen Economic Research.

In 2017 is gemiddeld $2,73 \mathrm{~m}^{3}$ hout per ha bos geoogst (tabel 2.4). Dat is evenals in 2016 een bescheiden volume, zeker in vergelijking met de jaren 2013-2015 met een gemiddeld houtoogstvolume van $3,6 \mathrm{~m}^{3}$ per jaar.

Tabel 2.4 Volume van de houtverkopen ( $m^{3}$ per ha) naar verkoopwijze, 2013-2017

\begin{tabular}{lrrrrrr} 
& 2013 & 2014 & 2015 & 2016 & 2,17 \\
Op stam & 3,54 & 3,49 & 3,14 & 2,54 & 0,48 \\
\hline Geveld & 0,26 & 0,16 & 0,20 & 0,24 & 2,25 \\
\hline Totaal & 3,80 & 3,64 & 3,34 & 2,73 & 2,78
\end{tabular}

Bron: Informatienet, Wageningen Economic Research.

De verkoop van hout als biomassa (stookhout) is een klein deel van de houtopbrengsten. Het ging daarbij in de afgelopen vijf jaar om een jaarlijks bedrag van gemiddeld 7 euro per ha bos. Vanaf 2012 wordt ook het volume van deze houtverkopen opgevraagd en geschat. De hoeveelheid van dit hout is in de jaren 2013-2017 ongeveer constant op 0,3 $\mathrm{m}^{3}$ per ha per jaar.

\section{Subsidies iets hoger}

Als bijdrage aan de maatschappelijke functies van het bos, zoals de duurzame instandhouding van het bos, ontving de particuliere boseigenaar in 2017 een gemiddelde vergoeding van 95 euro per ha bos (beheer- en overige subsidies, zie tabel 2.2), tegen 91 euro gemiddeld per jaar in de periode 2013- 
2016 (een plus van 4\%). Het grootste deel (ruim 80\% tussen 2013-2017) van de subsidies bestaat uit een structurele bijdrage aan de beheerkosten van het bos via de Provinciale Subsidieregeling Natuurbeheer (PSN).

De Provinciale Subsidieregeling Natuurbeheer (PSN) gaat geleidelijk over naar het Subsidiestelsel Natuur en Landschap (SNL). De subsidies voor natuur zijn hoger geworden, maar de beheersubsidie voor productiebos is in de nieuwe regeling veel lager dan in de oude. Voor actuele informatie over het SNL wordt verwezen naar de website van BIJ12 (www.bij12.nl).

De overige subsidies zijn in 2017 wat hoger dan het gemiddelde niveau in 2013-2016 (zie tabel 2.2). Deze subsidies zijn afkomstig van verschillende verstrekkers en hebben geen structureel karakter.

Overige opbrengsten constant

De overige bedrijfsopbrengsten lagen in 2017 op gemiddeld 65 euro per ha bos. Dat komt overeen met het gemiddelde niveau van jaren 2013-2016 (zie tabel 2.2). Voorbeelden hiervan zijn opbrengsten uit de verhuur van de jacht, verkoop van kerstbomen en -groen en recreatieactiviteiten.

\subsection{Kosten}

Gemiddelde kosten hoger

De gemiddelde kosten van het bosbeheer zijn in 2017 gestegen tot 315 euro per ha bos (tabel 2.5).

Dat is $8 \%$ meer dan een jaar eerder, en $12 \%$ boven de gemiddelde kosten in de periode 2013-2016.

Tabel 2.5 Kostensoorten (euro per ha bos) op particuliere bosbedrijven, 2013-2017

\begin{tabular}{|c|c|c|c|c|c|}
\hline & 2013 & 2014 & 2015 & 2016 & 2017 \\
\hline Arbeid uitvoerend & 72 & 73 & 74 & 77 & 85 \\
\hline Werktuigen en grondstoffen & 33 & 35 & 31 & 35 & 35 \\
\hline Heffingen en verzekeringen & 12 & 11 & 8 & 8 & 8 \\
\hline Totaal & 281 & 273 & 279 & 289 & 315 \\
\hline
\end{tabular}

Bron: Informatienet, Wageningen Economic Research.

De kosten van de drie belangrijkste posten - beheer, leiding en toezicht, arbeid uitvoerend en werk door derden - zijn in 2017 met ongeveer hetzelfde bedrag toegenomen. Samen zijn deze posten in 2017 goed voor circa $80 \%$ van de totale kosten (figuur 2.2). 


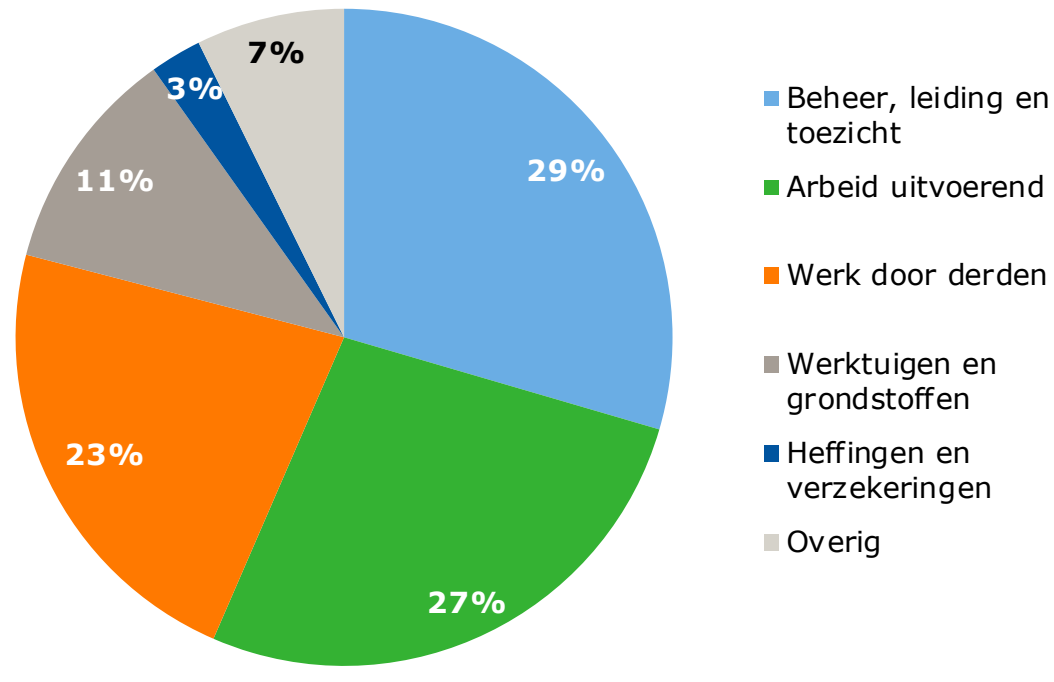

Figuur 2.2 Verdeling (\%) van de kosten op particuliere bosbedrijven naar kostensoorten, 2017 Bron: Informatienet, Wageningen Economic Research.

Een deel van het werk wordt door de eigenaar zelf uitgevoerd waarvoor een 'berekend loon' is opgenomen. In 2017 was dat gemiddeld ruim 50 euro per ha bos, ofwel 17\% van de totale kosten van het bosbeheer.

Beheer, leiding en toezicht grote kostenpost

De qua werkzaamheden grootste kostenpost is de post 'Algemene kosten' (tabel 2.6 en figuur 2.3). In 2017 bedroegen ze gemiddeld 124 euro per ha, waaronder 93 euro (75\%) voor beheer, leiding en toezicht. Daarnaast bestaan ze uit heffingen en verzekeringen en overige kosten (zoals voor administratieve dienstverlening).

Tabel 2.6 Kosten (euro per ha bos) op particuliere bosbedrijven naar kostenplaats, 2013-2017

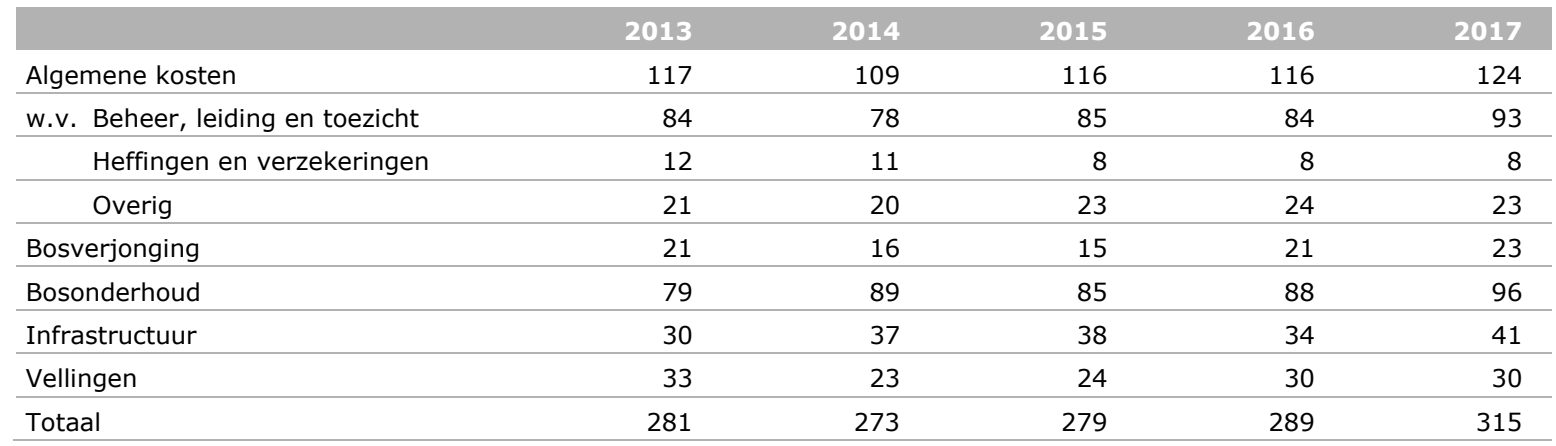

Bron: Informatienet, Wageningen Economic Research.

Het aandeel van de algemene kosten is geleidelijk gedaald tot $39 \%$ in 2017 , tegen gemiddeld $58 \%$ in de periode 2001-2005. Dat is vooral te danken aan de vermindering van de kosten van heffingen en verzekeringen. Zo waren de waterschapslasten 4 euro per ha in 2017, tegen gemiddeld ongeveer 20 euro per ha in de periode voor de invoering van het nieuwe heffingenstelsel in 2009. 


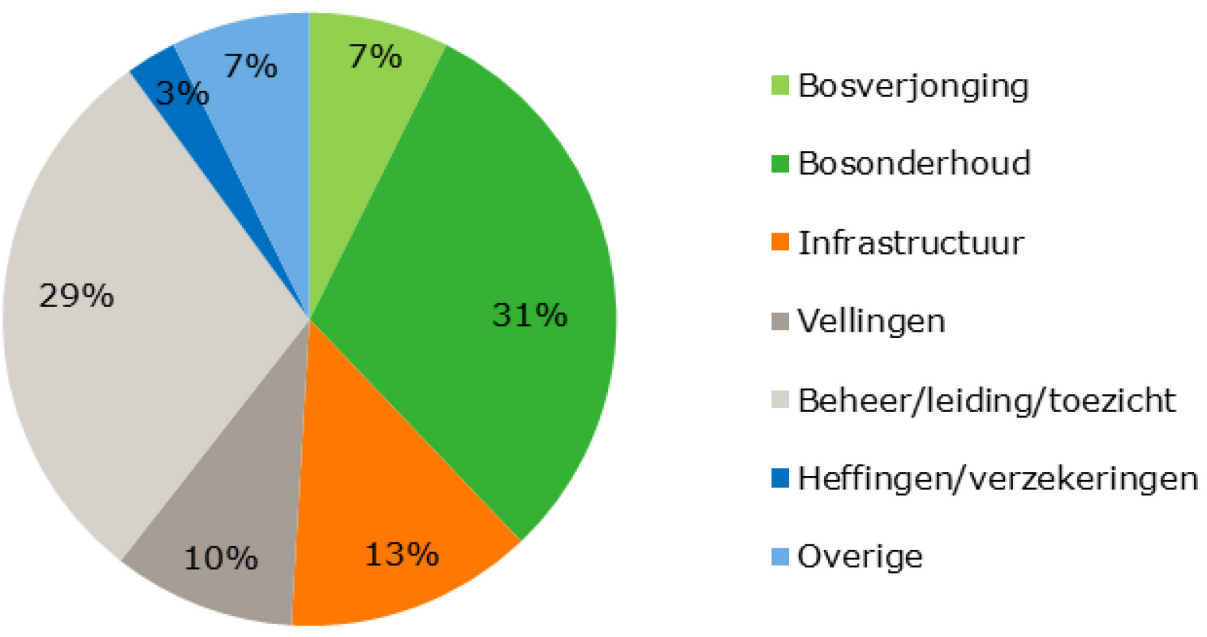

Figuur 2.3 Verdeling (\%) van de kosten op particuliere bosbedrijven naar kostenplaatsen, 2017 Bron: Informatienet, Wageningen Economic Research.

De kosten voor vellingen, bosverjonging, bosonderhoud en infrastructuur zijn in de afgelopen jaren gestegen, samen met de toename van de houtoogst. In de afgelopen vijf jaar (2013-2017) bedroegen de kosten gemiddeld 171 euro per jaar, tegenover 102 euro per ha tussen 2001 en 2005.

\subsection{Spreiding in resultaten}

Er zijn grote verschillen in resultaten tussen de particuliere bosbedrijven. In 2017 had $42 \%$ van de bedrijven een bedrijfsresultaat van minder dan -100 euro per ha, en $15 \%$ een resultaat van meer dan 100 euro per ha (tabel 2.7).

Tabel 2.7 Procentuele verdeling van particuliere bosbedrijven (met areaal bos) naar bedrijfsresultaat, 2015-2017

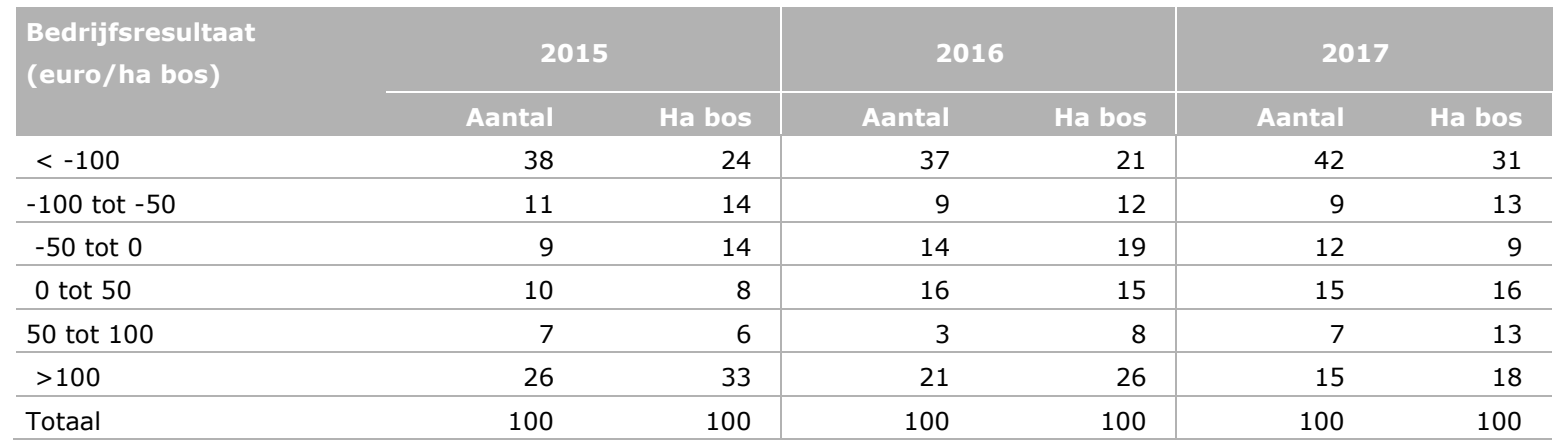

Bron: Informatienet, Wageningen Economic Research.

In de periode $2015-2017$ heeft gemiddeld $40 \%$ van de bedrijven een positief resultaat behaald. De bedrijven die uit de rode cijfers bleven, beheerden gemiddeld $48 \%$ van het bosareaal. 


\section{Resultaten naar bedrijfsgrootte}

\subsection{Resultaten grotere bedrijven (minstens 50 ha bos)}

Hogere resultaten voor grotere bedrijven

De grotere particuliere bosbedrijven (minstens 50 ha bos) boeken gemiddeld duidelijk hogere resultaten dan alle bedrijven. In 2017 hebben ze een licht negatief resultaat geboekt (tabel 3.1), na een aantal jaar met positieve resultaten. In de periode 2013-2017 heeft gemiddeld 55\% van de eigenaren een kostendekkende exploitatie gerealiseerd; deze groep eigenaren beheert ook 55\% van het bosareaal.

Tabel 3.1 Resultaten (euro per ha bos) van particuliere bosbedrijven groter dan 50 ha, 2013-2017

\begin{tabular}{lrrrrr} 
& 2013 & 2014 & 2015 & 2016 & 2017 \\
\hline Opbrengsten & 308 & 280 & 271 & 272 & 271 \\
\hline Kosten & 251 & 239 & 233 & 245 & 274 \\
\hline Bedrijfsresultaat & 57 & 40 & 38 & 27 & -3 \\
\hline Opbrengsten/kosten (\%) & 123 & 117 & 116 & 111 & 99 \\
\hline Inkomen uit het bosbedrijf & 70 & 54 & 52 & 41 & 11 \\
\hline
\end{tabular}

Bron: Informatienet, Wageningen Economic Research.

In 2017 waren de gemiddelde opbrengsten vrijwel gelijk aan de kosten, en resteerde voor de eigenaar een inkomen van 11 euro per ha bos. In de vier voorafgaande jaren (2013-2016) bedroeg het gemiddelde inkomen 54 euro per ha per jaar.

Beperkte inbreng eigen arbeid

Op de grotere bedrijven is de inbreng van de eigen arbeid (per ha) van de boseigenaar relatief beperkt en daarmee ook de bijdrage aan het inkomen. De hiervoor in rekening gebrachte bedragen waren in de afgelopen vijf jaar gemiddeld $6 \%$ van de totale kosten voor de grotere bedrijven, tegenover $16 \%$ voor alle bedrijven.

Tabel 3.2 Opbrengsten (euro per ha bos) van particuliere bosbedrijven groter dan 50 ha, 2013-2017

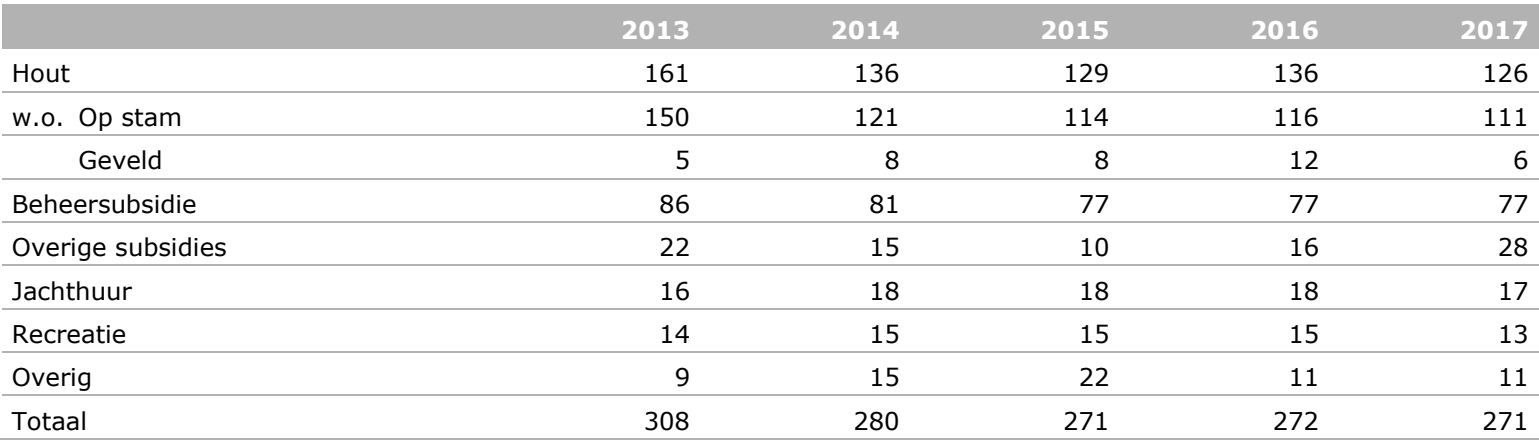

Bron: Informatienet, Wageningen Economic Research.

De gemiddelde opbrengsten op de grotere bedrijven (minimaal 50 ha bos) zijn in 2017 uitgekomen op 271 euro per ha bos (tabel 3.2), evenveel als in de twee voorgaande jaren. Ten opzichte van de jaren 2013-2016 ligt de opbrengst 4\% lager door een afname van alle opbrengstenposten met uitzondering van de overige subsidies. 
De gemiddelde kosten op de grotere bedrijven (minstens 50 ha bos) zijn in 2017 met 12\% toegenomen tot 274 euro per ha bos (tabel 3.3). De stijging komt voor rekening van de drie belangrijkste kostenposten: beheer, leiding en toezicht, arbeid uitvoerend en werk door derden.

Tabel 3.3 Kosten (euro per ha bos) op particuliere bosbedrijven groter dan 50 ha, 2013-2017

\begin{tabular}{|c|c|c|c|c|c|}
\hline & 2013 & 2014 & 2015 & 2016 & 2017 \\
\hline Arbeid uitvoerend & 50 & 53 & 53 & 51 & 61 \\
\hline Werktuigen en grondstoffen & 26 & 33 & 30 & 32 & 33 \\
\hline Heffingen en verzekeringen & 10 & 10 & 6 & 7 & 7 \\
\hline Totaal & 251 & 239 & 233 & 245 & 274 \\
\hline
\end{tabular}

Bron: Informatienet, Wageningen Economic Research.

\subsection{Resultaten naar bedrijfsgrootte}

Kleine bedrijven niet kostendekkend

De exploitatie van het bosbeheer is in de periode 2013-2017 gemiddeld genomen kostendekkend geweest: een plus van 5 euro per ha bos (tabel 3.4). Dat gold voor alle groepen bedrijven, behalve voor de kleinere bedrijven ( 5 tot 25 ha en 25 tot 50 ha; tabel 3.4).

Tabel 3.4 Resultaten (euro per ha bos per jaar) van particuliere bosbedrijven naar bedrijfsgrootte, gemiddelde 2013-2017

\begin{tabular}{|c|c|c|c|c|c|c|}
\hline & 5 tot & 25 tot & 50 tot & 100 tot & 250 ha & Alle \\
\hline & 25 ha & 50 ha & 100 ha & 250 ha & of meer & \\
\hline Opbrengsten & 411 & 191 & 280 & 335 & 258 & 292 \\
\hline Bedrijfsresultaat & -75 & -24 & -1 & 49 & 36 & 5 \\
\hline Opbrengsten/kosten (\%) & 86 & 89 & 103 & 117 & 116 & 102 \\
\hline
\end{tabular}

Bron: Informatienet, Wageningen Economic Research.

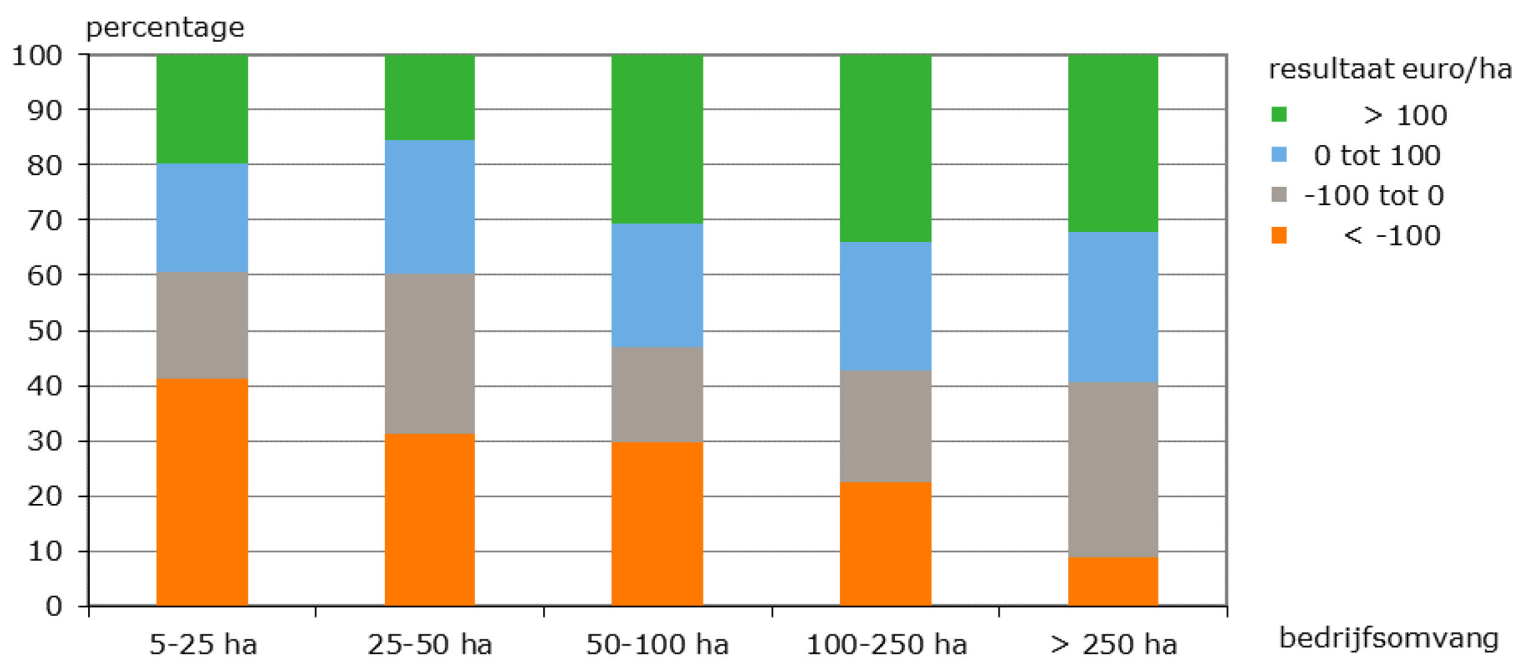

Figuur 3.1 Procentuele verdeling particuliere bosbedrijven naar bedrijfsresultaat en bedrijfsomvang, gemiddelde 2013-2017

Bron: Informatienet, Wageningen Economic Research. 
Over het algemeen lopen de bedrijfsresultaten op bij een toenemende bedrijfsomvang (ha bos) (figuur 3.1). In de groepen 5-25 ha en 25-50 ha heeft gemiddeld 40\% in de periode 2013-2017 een positief bedrijfsresultaat geboekt; voor de daarop volgende groepen loopt het aandeel met een positief resultaat op van $53 \%$ tot $59 \%$.

\subsection{Opbrengsten naar bedrijfsgrootte}

De groep kleinste bedrijven (5-25 ha) heeft in de periode 2013-2017 de hoogste opbrengst per ha, vooral dankzij overige opbrengsten (tabel 3.5). Deze bestaan onder meer uit de verkoop van kerstbomen en -groen, maar vooral uit recreatieopbrengsten. De gemiddelde opbrengsten op de bedrijven met meer dan 250 ha liggen ongeveer op het gemiddelde niveau van de middengroepen (25-250 ha).

Tabel 3.5 Opbrengsten (euro per ha bos per jaar) van particuliere bosbedrijven naar bedrijfsgrootte, gemiddelde 2013-2017

\begin{tabular}{lrrrrrrr} 
& $\begin{array}{r}5 \text { tot } \\
25 \text { ha }\end{array}$ & $\begin{array}{l}25 \text { tot } \\
50 \text { ha }\end{array}$ & $\begin{array}{r}50 \text { tot } \\
100 \text { ha }\end{array}$ & $\begin{array}{r}100 \text { tot } \\
250 \text { ha }\end{array}$ & $\begin{array}{r}250 \text { ha } \\
\text { of meer }\end{array}$ & Alle \\
Hout & 158 & 81 & 150 & 139 & 133 & 134 \\
\hline Beheersubsidie & 59 & 69 & 81 & 104 & 69 & 75 \\
\hline Overige subsidies & 21 & 7 & 13 & 34 & 14 & 17 \\
\hline Overig & 172 & 34 & 36 & 57 & 42 & 67 \\
\hline Totaal & 411 & 191 & 280 & 335 & 258 & 292 \\
\hline
\end{tabular}

Bron: Informatienet, Wageningen Economic Research.

Houtopbrengsten en beheersubsidies waren in de periode 2013-2017 met een gemiddeld aandeel van respectievelijk $46 \%$ en $26 \%$ de belangrijkste opbrengstenposten. Daarna volgden de overige opbrengsten (23\%) en de overige subsidies (6\%).

Op de kleinste bedrijven is het aandeel van de overige opbrengsten relatief groot. De opbrengst uit de beheersubsidie is op de kleinste bedrijven het laagst. Van oudsher zijn in deze groep minder eigenaren die een beroep doen op deze bijdrage aan de beheerkosten. De reden hiervan is niet onderzocht, maar kan te maken hebben met het niet willen (of kunnen) voldoen aan de voorwaarden die bij de beheersubsidie horen (bijvoorbeeld de daarvoor benodigde inspanningen, of het niet willen openstellen van het bos).

\subsection{Kosten naar bedrijfsgrootte}

De totale gemiddelde kosten per ha bos (287 euro) bestonden in de jaren 2013-2017 voor 33\% uit werk door derden, waaronder rentmeester en loonwerker, en voor $45 \%$ uit loonkosten, waaronder de berekende vergoeding voor de inzet van de arbeid van de eigenaar. Deze vergoeding ligt in de bedrijfsgrootte van 5-25 ha veel hoger dan in de andere klassen (tabel 3.6). Een belangrijk verschil in kostenbouw tussen enerzijds de groepen tussen de 25 en 250 ha en anderzijds de groep boven de 250 ha, is het in dienst hebben van personeel. De bedrijven met meer dan 250 ha geven hier absoluut en relatief meer aan uit, maar hebben daardoor minder kosten die zijn samengevat onder de post 'Rentmeester'. 
Tabel 3.6 Kosten (euro per ha bos per jaar) op particuliere bosbedrijven naar kostensoort en bedrijfsgrootte, gemiddelde 2013-2017

\begin{tabular}{|c|c|c|c|c|c|c|}
\hline & 5 tot & 25 tot & 50 tot & 100 tot & 250 ha & Alle \\
\hline & 25 ha & 50 ha & 100 ha & 250 ha & of meer & \\
\hline Lonen, berekend & 224 & 66 & 33 & 29 & 8 & 63 \\
\hline Rentmeester a) & 37 & 40 & 52 & 50 & 25 & 37 \\
\hline Overig werk door derden & 57 & 46 & 74 & 63 & 50 & 56 \\
\hline Heffingen en verzekeringen & 13 & 12 & 9 & 12 & 6 & 9 \\
\hline Overig & 86 & 36 & 42 & 45 & 38 & 48 \\
\hline Totaal & 485 & 215 & 281 & 286 & 221 & 287 \\
\hline
\end{tabular}

a) Rentmeester, bosgroep en ingenieursbureau.

Bron: Informatienet, Wageningen Economic Research.

\subsection{Kostenplaatsen en bedrijfsgrootte}

De eigenaren met minder dan 25 ha bos hebben veruit de hoogste kosten per ha, vooral voor algemene kosten, bosonderhoud en infrastructuur (tabel 3.7). Het verschil in kosten tussen de overige onderscheiden bosgroottes is veel minder groot.

Tabel 3.7 Kosten (euro per ha bos per jaar) op particuliere bosbedrijven naar kostenplaats en bedrijfsgrootte, gemiddelde 2013-2017

\begin{tabular}{|c|c|c|c|c|c|c|}
\hline & 5 tot & 25 tot & 50 tot & 100 tot & 250 ha & Alle \\
\hline & 25 ha & 50 ha & 100 ha & 250 ha & of meer & \\
\hline Algemene kosten & 179 & 105 & 99 & 136 & 89 & 116 \\
\hline Heffingen en verzekeringen & 13 & 12 & 9 & 12 & 6 & 9 \\
\hline Overig & 49 & 20 & 14 & 19 & 14 & 22 \\
\hline Bosonderhoud & 164 & 60 & 93 & 74 & 64 & 87 \\
\hline Infrastructuur & 72 & 23 & 36 & 27 & 27 & 36 \\
\hline Vellingen & 52 & 17 & 38 & 23 & 19 & 28 \\
\hline Totaal & 485 & 215 & 281 & 286 & 221 & 287 \\
\hline
\end{tabular}

Bron: Informatienet, Wageningen Economic Research. 


\section{$4 \quad$ Resultaten naar regio}

\subsection{Bedrijfsresultaten naar regio}

\section{Inkomen in Centrum negatief}

De bosbedrijven in de regio's verschillen qua bedrijfsvoering en bedrijfsresultaten sterk van elkaar. In het Centrum liggen de opbrengsten en kosten van het bosbeheer relatief hoog, zowel door een hogere houtoogst als door het intensievere gebruik van het bos voor andere activiteiten, zoals recreatie (boscampings, verhuur van bos aan hondenclubs, scouts en militairen, en verhuur van het bos voor rally's, crosscountry's enzovoort).

In de regio Centrum sloten de particuliere boseigenaren 2017 af met een gemiddeld resultaat onder 100 euro per ha bos, tegen een gemiddeld jaarlijks verlies van 13 euro in de vier voorafgaande jaren (tabel 4.1). Voor de eigenaar resteerde er een negatief inkomen uit het bosbedrijf.

Particuliere boseigenaren in Noordoost hebben in 2017 ook een negatief bedrijfsresultaat geboekt: gemiddeld -20 euro per ha bos. Dat is flink onder het gemiddelde in de vier voorgaande jaren (20132016), waarin een positief resultaat van bijna 40 euro per ha werd geboekt (tabel 4.1). Het inkomen uit bosbedrijf - het bedrijfsresultaat plus de berekende vergoeding van de eigen arbeid - is in 2017 uitgekomen op 49 euro per ha.

Ook voor de particuliere boseigenaren in de regio Zuid resteerde over 2017 een negatief resultaat: -11 euro per ha bos, tegen een positief resultaat van 21 euro per ha per jaar in de jaren 2013-2016 (tabel 4.1). Het verschil tussen het inkomen en het resultaat is in de regio Zuid lager dan in beide andere regio's door een minder grote inzet van eigen arbeid.

Tabel 4.1 Resultaten (euro per ha bos per jaar) van particuliere bosbedrijven naar regio, 2013-2017

\begin{tabular}{|c|c|c|c|c|c|c|}
\hline & \multicolumn{2}{|c|}{ Noordoost } & \multicolumn{2}{|c|}{ Centrum } & \multicolumn{2}{|c|}{ Zuid } \\
\hline Opbrengsten & 309 & 288 & 390 & 360 & 176 & 139 \\
\hline Bedrijfsresultaat & 37 & -20 & -13 & -104 & 21 & -11 \\
\hline Opbrengsten/kosten (\%) & 114 & 93 & 97 & 78 & 114 & 93 \\
\hline
\end{tabular}

Bron: Informatienet, Wageningen Economic Research.

\subsection{Opbrengsten naar regio}

Tussenpositie voor Noordoost

De gemiddelde opbrengst in de regio Centrum in 2017 was 360 euro per ha, 8\% lager dan de gemiddelde jaaropbrengst in de periode 2013-2016 (tabel 4.2). In de regio Zuid realiseerden de particuliere bosbedrijven een gemiddelde opbrengst van 139 euro per ha bos, een vijfde minder dan in periode 2013-2016. Qua opbrengsten neemt de regio Noordoost een tussenpositie in: in 2017 waren deze 288 euro per ha bos, 7\% onder jaargemiddelde in de periode 2013-2016. In deze regio zijn zowel de gemiddelde houtopbrengsten als de overige subsidies hoger dan in de andere regio's. 
Tabel 4.2 Opbrengsten (euro per ha bos per jaar) van particuliere bosbedrijven naar regio, 2013-2017

\begin{tabular}{|c|c|c|c|c|c|c|}
\hline & \multicolumn{2}{|c|}{ Noordoost } & \multicolumn{2}{|c|}{ Centrum } & \multicolumn{2}{|c|}{ Zuid } \\
\hline & $2013 / 2016$ & 2017 & $2013 / 2016$ & 2017 & $2013 / 2016$ & 2017 \\
\hline Hout & 170 & 146 & 152 & 114 & 78 & 52 \\
\hline Geveld & 17 & 19 & 10 & 15 & 4 & 2 \\
\hline Beheersubsidie & 77 & 75 & 86 & 77 & 61 & 64 \\
\hline Jachthuur & 9 & 9 & 23 & 23 & 13 & 14 \\
\hline Recreatie & 12 & 12 & 68 & 75 & 16 & 6 \\
\hline Overig & 15 & 12 & 50 & 50 & 1 & 1 \\
\hline Totaal & 309 & 288 & 390 & 360 & 176 & 139 \\
\hline
\end{tabular}

Bron: Informatienet, Wageningen Economic Research.

\subsection{Kosten naar regio}

Hoge kosten in Centrum

De gemiddelde kosten per ha bos verschillen ook sterk per regio: ze zijn het hoogst in de regio Centrum en het laagst in de regio Zuid (tabel 4.3). De hogere kosten in de regio Centrum hangen samen met een meer intensief (recreatief) gebruik van het bos. In vergelijking met de jaren 20132016 zijn de kosten met 15\% gestegen tot 464 euro per ha bos (tabel 4.3). De gemiddelde kosten in de regio Zuid lagen in 2017 op slechts 150 euro per ha bos, net iets onder het gemiddelde niveau in de jaren 2013-2016. De gemiddelde kosten in de regio Noordoost lagen in 2017 met 308 euro per ha ruim boven die in de periode 2013-2016.

Tabel 4.3 Kosten (euro per ha bos per jaar) op particuliere bosbedrijven naar regio, 2013-2017

\begin{tabular}{|c|c|c|c|c|c|c|}
\hline & \multicolumn{2}{|c|}{ Noordoost } & \multicolumn{2}{|c|}{ Centrum } & \multicolumn{2}{|c|}{ Zuid } \\
\hline & $2013 / 2016$ & 2017 & $2013 / 2016$ & 2017 & $2013 / 2016$ & 2017 \\
\hline Beheer, leiding en toezicht & 80 & 95 & 93 & 101 & 75 & 79 \\
\hline Werk door derden & 66 & 77 & 72 & 97 & 34 & 29 \\
\hline Werktuigen en grondstoffen & 34 & 37 & 49 & 53 & 15 & 12 \\
\hline Overig & 17 & 18 & 40 & 40 & 9 & 10 \\
\hline Totaal & 272 & 308 & 404 & 464 & 155 & 150 \\
\hline
\end{tabular}

Bron: Informatienet, Wageningen Economic Research. 


\section{$5 \quad$ Resultaten in historisch perspectief}

\subsection{Bedrijfsresultaten op lange termijn}

In de ontwikkeling van het bedrijfsresultaat per ha bos zijn over de laatste decennia verschillende pieken en dalen te onderscheiden. Tot 2015 is een opgaande lijn zichtbaar, maar daarna is die gekeerd (figuur 5.1).

In het stormjaar 1990 had de niet-geplande toename van het volume van de houtoogst eenmalig een hoger bedrijfsresultaat per ha tot gevolg. Ook in 1994 en 1995 was er een tijdelijke opleving door een hoger volume van de houtoogst. Toen maakten veel boseigenaren op het laatste moment nog gebruik van de aflopende herplantsubsidie. Nog rooskleuriger waren de resultaten in de jaren 2006-2007 en 2010-2015, vooral dankzij de houtopbrengsten.

De fluctuaties in het bedrijfsresultaat uit de bosbouwactiviteiten zijn door de jaren heen over het algemeen vrij groot, met negatieve en positieve uitschieters zoals in 1993 en 2007. Het gemiddelde reële tekort in de gehele periode (1989-2017) van alle bedrijven komt uit op 38 euro per ha bos per jaar; de grotere bedrijven (meer dan 50 ha bos) realiseerden in deze periode een bescheiden positief resultaat van 5 euro per ha bos.

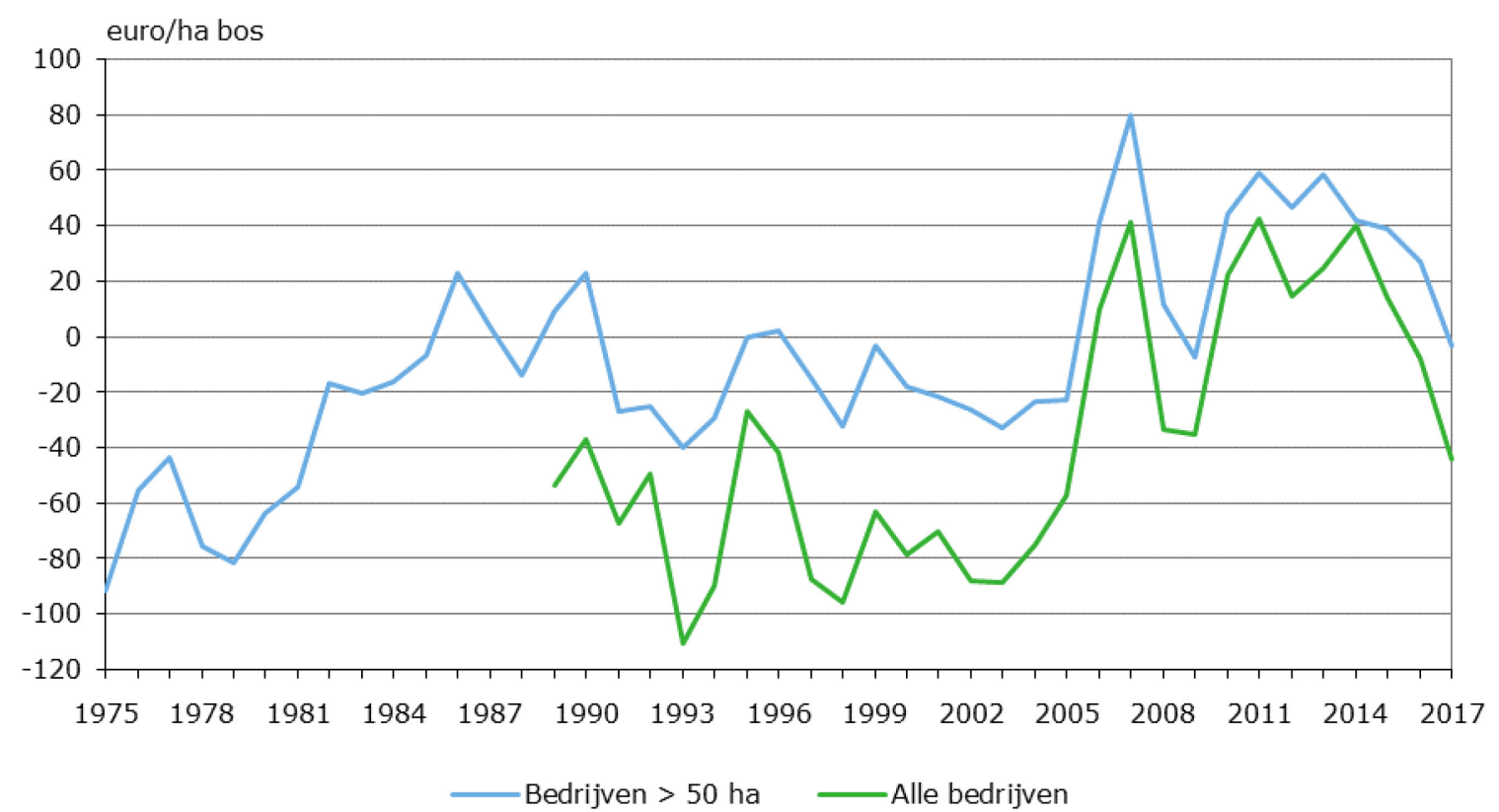

Figuur 5.1 Ontwikkeling van het gemiddelde reële bedrijfsresultaat per ha bos (in euro's van 2017) van particuliere bosbedrijven, 1975-2017

Bron: Informatienet, Wageningen Economic Research.

\subsection{Kosten en opbrengsten van alle bedrijven}

De gemiddelde reële kosten schommelden op de particuliere bosbedrijven in de periode 1989-2017 tussen 260 en 340 euro per ha bos per jaar (figuur 5.2); gemiddeld lagen ze bijna op 300 euro per ha per jaar. Tot de eeuwwisseling is het kostenniveau - los van jaarlijkse schommelingen - globaal gelijk gebleven; de kosten zijn tot 2010 met onderbrekingen licht gedaald, maar daarna weer opgelopen. 


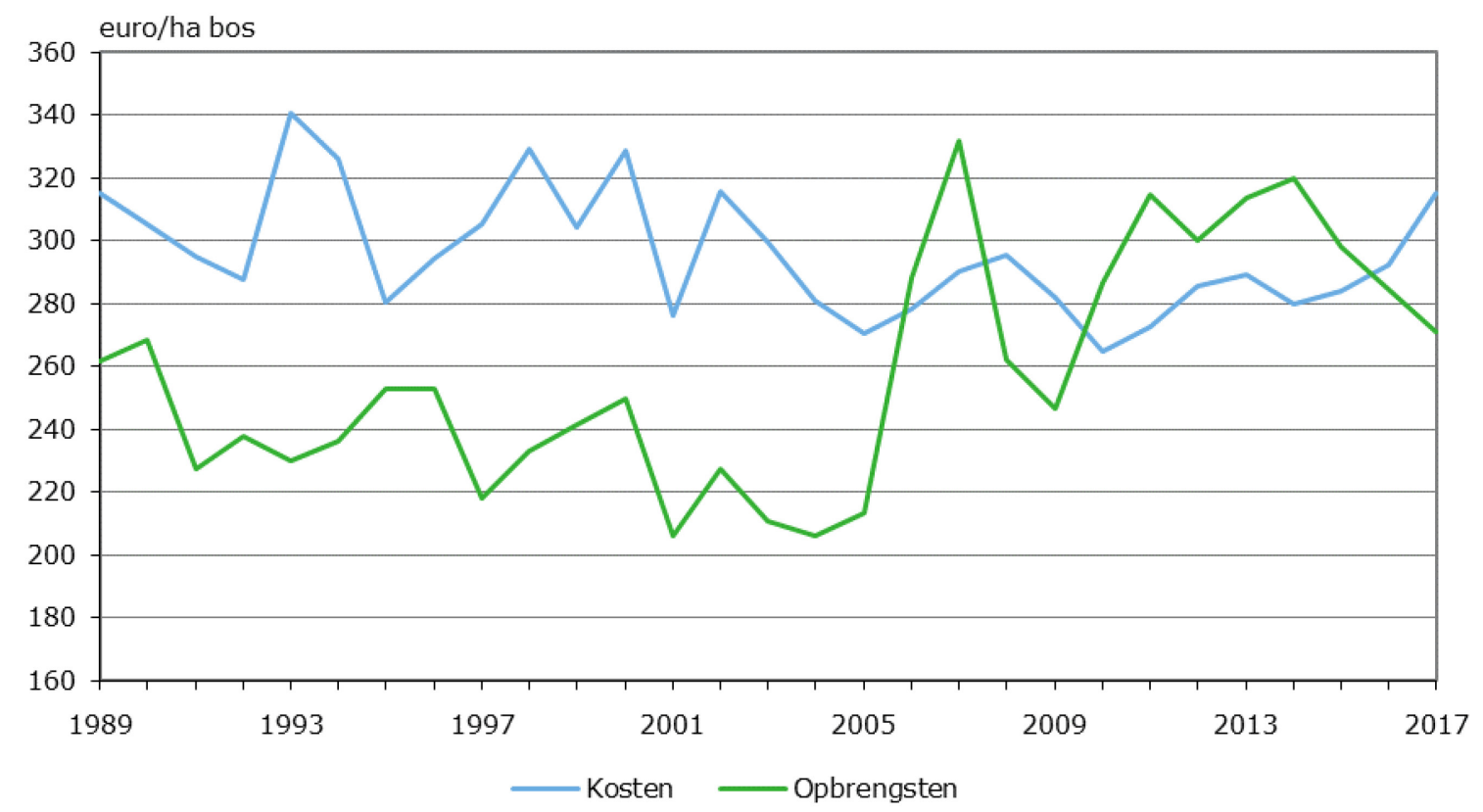

Figuur 5.2 Reële kosten en opbrengsten per ha bos (in euro's van 2017) op particuliere bosbedrijven, 1989-2017

Bron: Informatienet, Wageningen Economic Research.

De reële opbrengsten bewogen zich tussen 1989 en 2005 op jaarbasis tussen 210 en 270 euro per ha per jaar; gemiddeld bedroegen ze 230 euro. In deze periode zijn de opbrengsten ook met onderbrekingen gedaald. Die ontwikkeling is door met name de hogere houtopbrengsten gekeerd. In de periode 2006-2017 zijn de opbrengsten gemiddeld 290 euro per ha per jaar geweest, zo'n 40\% meer dan rond 2005.

\subsection{Kosten en opbrengsten van grotere bedrijven}

Op de bedrijven met meer dan 50 ha bos zijn de reële kosten met ruim $40 \%$ teruggedrongen, van gemiddeld 430 euro per ha per jaar tussen 1975-1980 tot 240 euro in de laatste vijf jaar. De grootste daling vond plaats vóór 1990. De ontwikkeling van de opbrengsten verliep tot 2005 volgens het patroon van de kosten; daarna stegen de houtopbrengsten onder invloed van de hogere houtprijzen. De totale reële opbrengsten lagen in de jaren 1975-1980 op gemiddeld ongeveer 360 euro per ha per jaar en in de laatste vijf jaar op 290 euro per ha, een vijfde lager. Tussen 2001 en 2005 werd een dieptepunt van 220 euro per ha per jaar bereikt (figuur 5.3). 


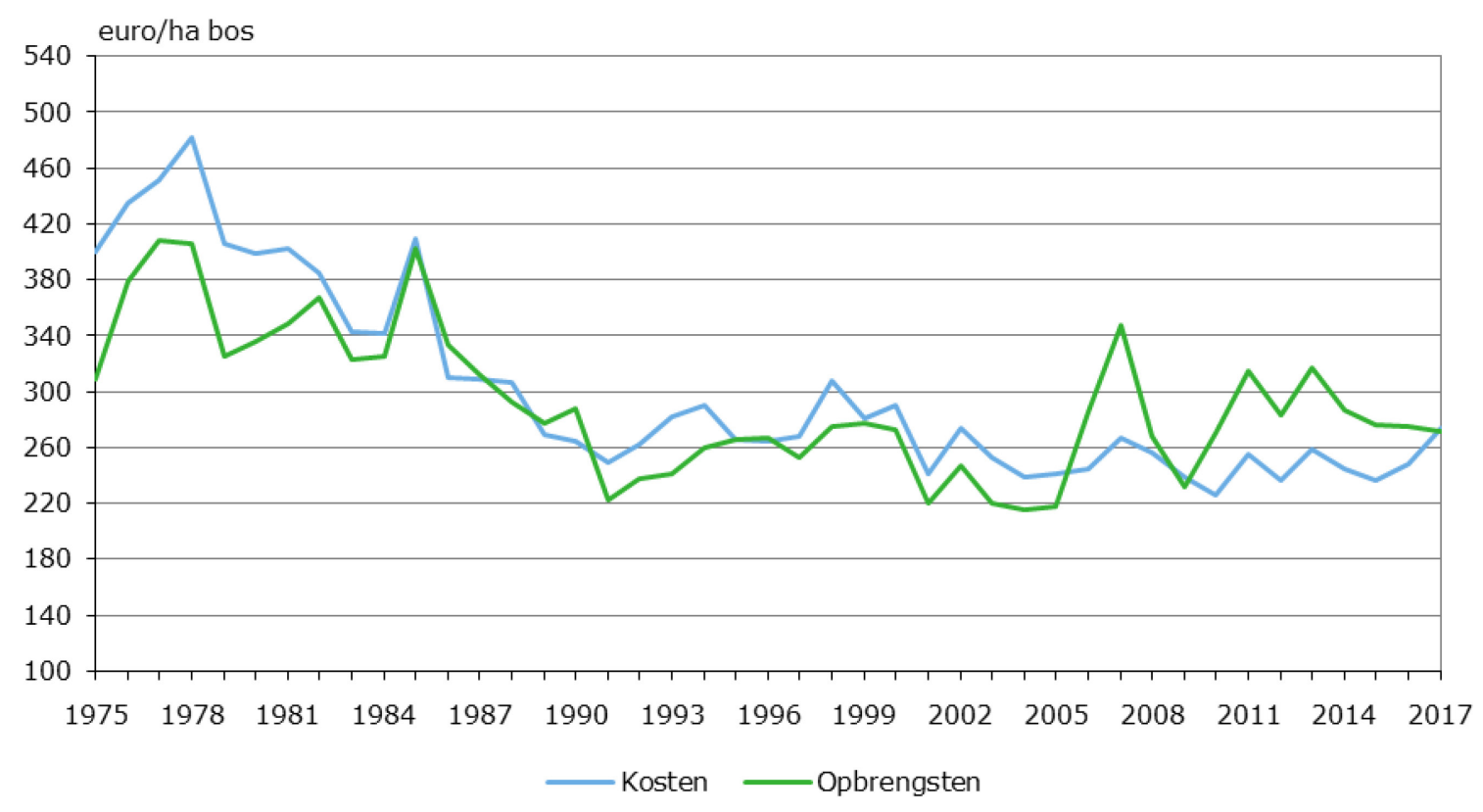

Figuur 5.3 Reële kosten en opbrengsten per ha bos (in euro's van 2017) op particuliere bosbedrijven groter dan 50 ha, 1975-2017

Bron: Informatienet, Wageningen Economic Research.

De reële houtopbrengst op de bedrijven met meer dan 50 ha bos schommelde tot 1990 rond de 130 euro per ha per jaar, zakte tot minder dan 60 euro in de jaren 2003-2005, maar is daarna hersteld tot gemiddeld tot rond de 140 euro per jaar in de afgelopen vijf jaar (figuur 5.4).

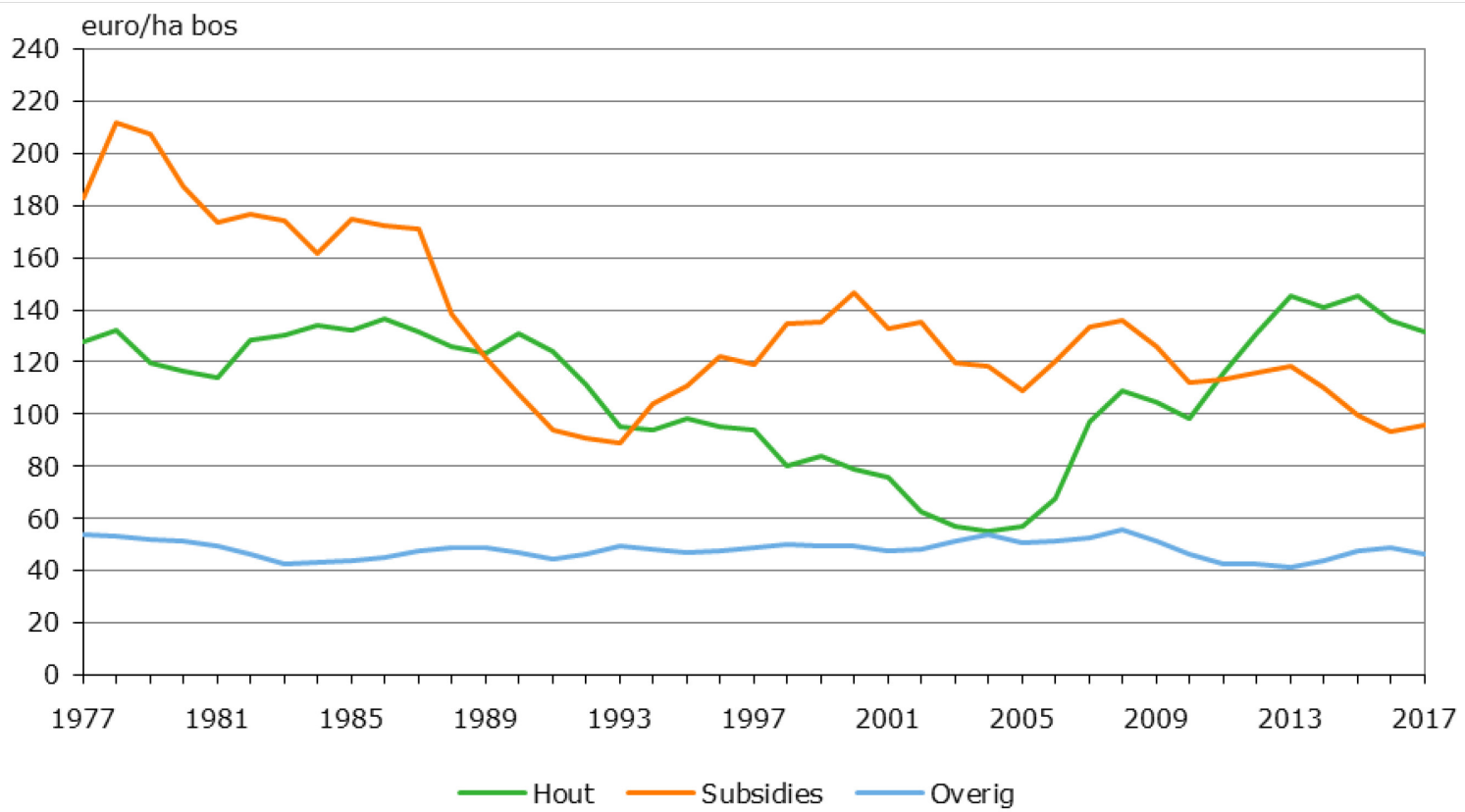

Figuur 5.4 Reële opbrengsten per ha bos (in euro's van 2017) van bedrijven groter dan 50 ha, voortschrijdend driejaarlijks gemiddelde 1975-2017

Bron: Informatienet, Wageningen Economic Research.

De ontwikkeling van de reële subsidies die de eigenaren met meer dan 50 ha bos sinds 1975 hebben ontvangen, vertoont een grillig verloop (figuur 5.4). Van de tweede helft van de jaren zeventig tot begin jaren negentig daalden de subsidies van circa 200 tot 90 euro per ha bos per jaar. Daarna trad een gedeeltelijk herstel op tot rond de eeuwwisseling (140 euro). De piek rond de eeuwwisseling heeft 
onder meer te maken met de verstrekte subsidies in die periode op basis van de Regeling effectgerichte maatregelen in bossen en natuurterreinen (EGM), een instrument voor het uitvoeren van het Overlevingsplan Bos en Natuur (OBN). Daarnaast waren er ook wat meer incidentele bijdragen (overige subsidies) van andere overheden (zoals provincies). In de meest recente jaren zijn de subsidies net iets onder de 100 euro per ha per jaar uitgekomen. De overige bedrijfsopbrengsten lagen in al die jaren tussen 40 en 60 euro per ha bos per jaar.

\subsection{Houtprijzen en oogstvolume}

In de periode 1989-2002 is de daling van de reële houtopbrengst in gang gezet door zowel de prijs als het volume van de houtoogst (figuur 5.5). Het houtoogstvolume nam af van gemiddeld $3,3 \mathrm{~m}^{3}$ per ha in de eerste helft van de jaren negentig tot $2,4 \mathrm{~m}^{3}$ per ha in 2002. Dat hield verband met het wegvallen van de herplantsubsidie (per 1 januari 1994) en de sterke daling van de reële houtprijzen. De eindvelling verdween, terwijl dit niet werd gecompenseerd door meer dunning. Door het veranderde bosbeheer nam de houtvoorraad toe en veranderde de leeftijdsopbouw van het bos (ouder).

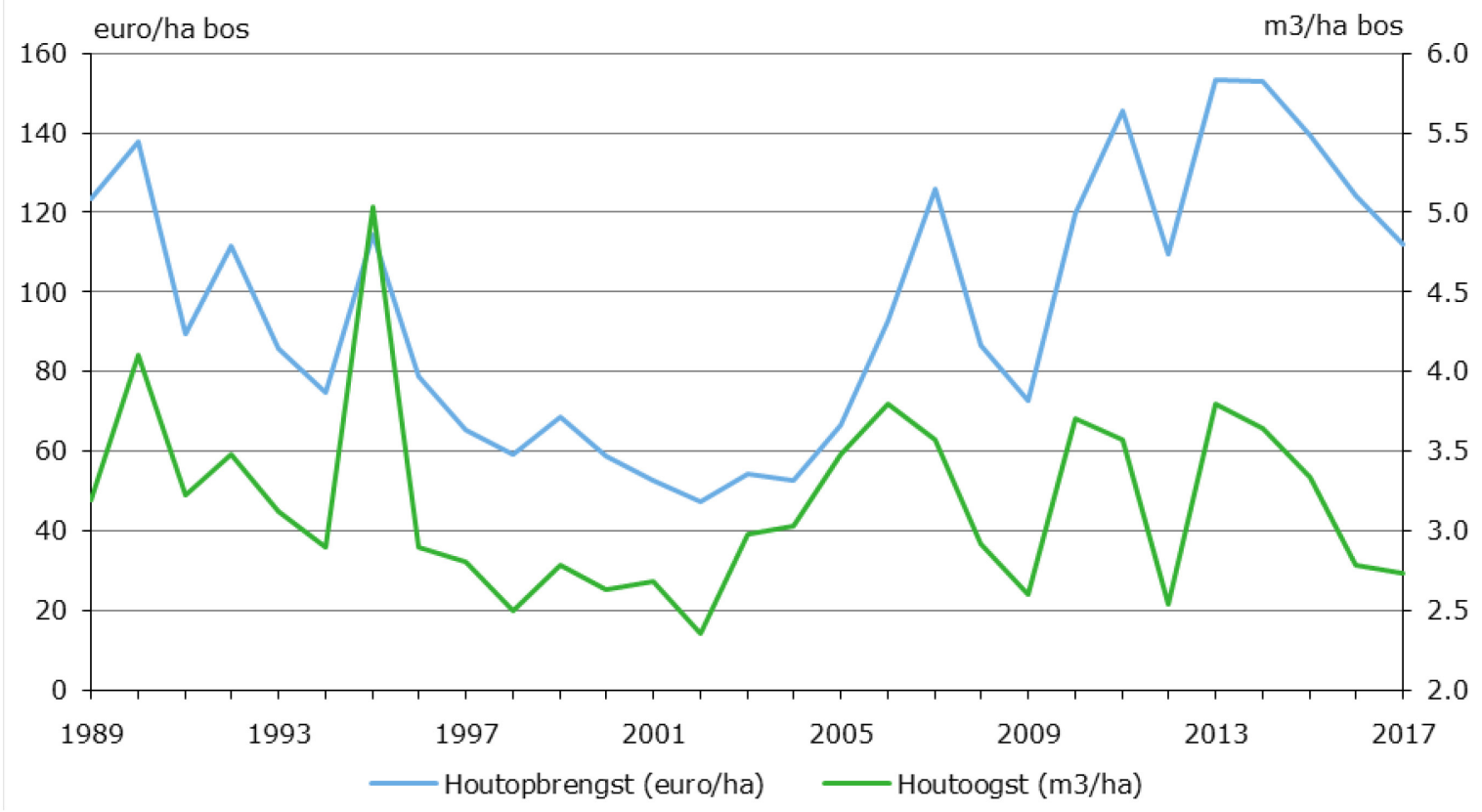

Figuur 5.5 Houtoogst ( $m^{3}$ per ha) en reële houtopbrengsten per ha bos (in euro's van 2017) van particuliere bosbedrijven, 1989-2017

Bron: Informatienet, Wageningen Economic Research.

Met de stijging van de houtprijzen na 2005 is het gemiddelde oogstvolume toegenomen tot 3,3 $\mathrm{m}^{3}$ per ha (2005-2017). Op de grotere bedrijven (meer dan 50 ha bos) is sinds 1975 in slechts enkele jaren meer geoogst dan $4 \mathrm{~m}^{3}$ per ha: 4,1 $\mathrm{m}^{3}$ in 1990 (stormjaar), 4,4 $\mathrm{m}^{3}$ in 1995 (aflopen herplantsubsidie) en $4,1 \mathrm{~m}^{3}$ in 1999 . 


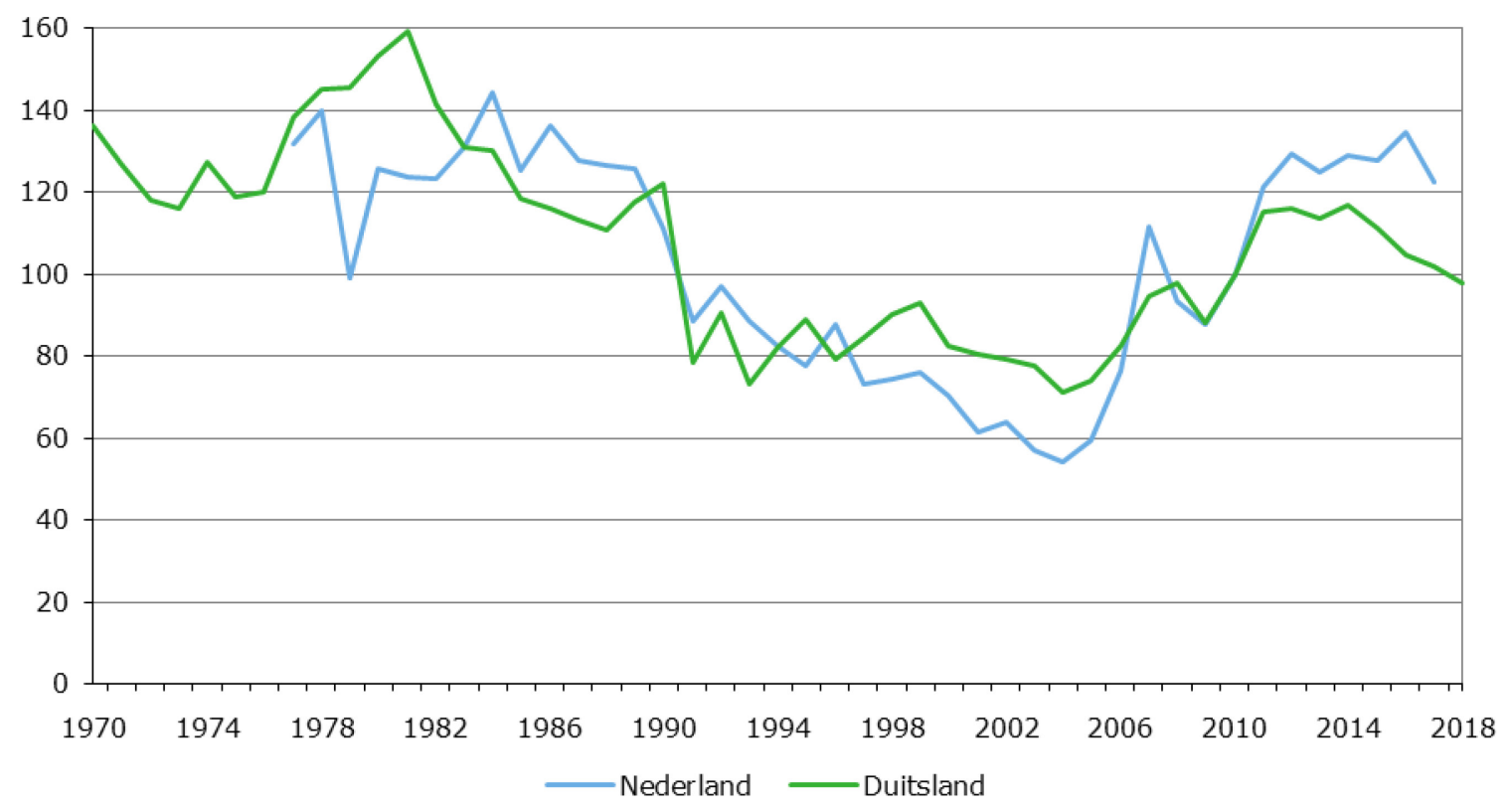

Figuur 5.6 Ontwikkeling reële houtprijs (2010=100), 1970-2018

Bron: Statistisches Bundesamt, Wageningen Economic Research, OESO-prijsindexcijfers bruto binnenlands product. De (geïndexeerde) houtprijs voor Nederland loopt tot 2017; die van Duitsland is ook beschikbaar voor 2018.

De gemiddelde reële houtprijs in Nederland lag in 2016 en 2017 op het niveau van de jaren tachtig, maar op het dieptepunt in 2004 zo'n 60\% lager. In figuur 5.6 is de ontwikkeling van de reële houtprijs in Nederland (vanaf 1977) en het grote buurland en handelspartner Duitsland (vanaf 1970) weergegeven. De ontwikkelingen lopen in grote lijnen gelijk op, wat illustreert dat de houtmarkt internationaal is. 


\section{Literatuur en websites}

Jansen, P. en M. Vonk, 2007. Houtprijzen. In: Vakblad Natuur Bos Landschap 4 (2), p. 27.

OBV (Onderlinge Bossen Verzekeringen), 7 februari 2007. Forse schade voor Nederlandse bossen na januaristorm. Arnhem: Persbericht OBV. www.bossenverzekering.nl

OBV (Onderlinge Bossen Verzekeringen), 2011. Jaarverslag 2010. www.bossenverzekering. nl

PHN en LNV (Platform Hout Nederland) en ministerie van LNV, 2005. Multifunctionaliteit in balans. Visie op de houtoogst. Wageningen/Den Haag: PHN/LNV.

Schelhaas, M., A.P.P.M. Clerkx, W.P. Daamen, J.F. Oldenburger, G. Velema, P. Schnitger, P. Schoonderwoerd en $\mathrm{H}$. Kramer, 2014. Zesde Nederlandse bosinventarisatie : methoden en basisresultaten (Alterra-rapport 2545). Wageningen.

\section{Websites}

www.agrimatie.nl

www.bij12.nl

www.knbv.nl

www.probos.nl

www.vbne.nl

www.wur.nl 


\title{
Bijlage 1 Begrippen
}

\section{B1.1 Bedrijfsresultaat en inkomen}

\author{
Bedrijfsresultaat \\ Het bedrijfsresultaat is het saldo van opbrengsten en kosten, en geeft aan of de bosbouwactiviteiten \\ bedrijfseconomisch rendabel zijn, dan wel in hoeverre de veronderstelde beloningsaanspraken van de \\ productiefactoren worden gehonoreerd. Overigens worden geen rentekosten berekend over het in \\ grond en houtopstand geïnvesteerde vermogen.
}

\section{Opbrengsten-kostenverhouding (\%)}

Het bedrijfsresultaat is een bedrag waarvan de relatieve rentabiliteit niet zonder meer is af te lezen: 10.000 euro als beloning voor 100.000 euro aan kosten is veel beter dan 10.000 euro als beloning voor 1 miljoen euro aan kosten. Omdat bovendien de waarde van het geld verandert (inflatie), is het aantrekkelijk om met een dimensieloos kengetal te werken. Dit is de verhouding tussen opbrengsten en kosten (in procenten). Een bedrijfsresultaat van 10.000 euro op 100.000 euro aan kosten betekent een opbrengsten-kostenverhouding van $110 \%$. Als deze verhouding onder de $100 \%$ ligt, blijft het resultaat achter bij de veronderstelde beloningsaanspraken van de productiefactoren.

\section{Inkomen uit het bosbedrijf}

Het inkomen uit het bosbedrijf wordt berekend door het bedrijfsresultaat te vermeerderen met de berekende arbeidskosten van de eigenaar en de overige berekende lonen. Het inkomen uit het bosbedrijf geeft weer wat de beloning is van de eigenaar voor risico, management en arbeid.

\section{B1.2 Opbrengsten}

\section{Houtopbrengsten}

De houtopbrengsten bestaan uit het tot en met 31 december van het betreffende jaar op stam dan wel geveld verkochte hout. Het komt weinig voor dat er op 31 december niet-verkochte voorraden geveld hout op het bosbedrijf aanwezig zijn. Daarom zijn eventuele voorraadcijfers niet in de exploitatierekening van het betreffende boekjaar verwerkt. Voorschotten en afrekeningen worden verwerkt in het jaar van ontvangst.

\section{Overige houtopbrengsten}

De overige houtopbrengsten bestaan uit verkoop van afvalhout, brandhout, houtchips en boerengeriefhout.

\section{Subsidies en bijdragen}

In het verleden konden boseigenaren onder meer in aanmerking komen voor een vaste hectarevergoeding van de overheid op basis van een door het Staatsbosbeheer goedgekeurd beheersplan. Met ingang van 1 september 1988 is de Regeling Bosbijdragen samen met een aantal andere subsidieregelingen vervangen door de Regeling Bijdragen Bos- en Landschapsbouw. Hierin is een vaste bijdrage voor het onderdeel 'duurzame instandhouding' van bos opgenomen. Met ingang van 1994 is deze regeling (gedeeltelijk) vervangen door de Regeling Functiebeloning Bos en Natuurterreinen.

Programma Beheer: Subsidieregeling natuurbeheer 2000

Per 1 januari 2000 is voor een groot aantal bedrijven de Regeling Functiebeloning vervangen door de regelingen van het Programma Beheer. Deze regeling beoogt particulieren bij het natuurbeheer te betrekken. Er worden subsidies verstrekt op basis van zogenoemde doelpakketten. Voor particuliere boseigenaren zijn de belangrijkste pakketten: (1) bos, (2) bos met verhoogde natuurwaarde en 
(3) natuurbos. In 2012 golden de volgende vergoedingen (provinciale regeling), ingedeeld naar soort subsidie:

- Beheersubsidie, voor instandhouding van basispakket bos (55,37 euro per ha), pluspakket bos (74,99 euro per ha) en natuurbos (83,06 euro per ha). Het terrein waarvoor subsidie is aangevraagd moet ten minste 358 dagen kosteloos worden opengesteld. De aparte toeslag voor openstelling $(10,19$ euro per ha in 2003) is vervallen. Ontheffing van de verplichting tot openstelling is in bijzondere omstandigheden mogelijk, bijvoorbeeld op grond van zwaarwegende natuurwetenschappelijke belangen.

- Inrichtingssubsidie, voor het eenmalig creëren van een betere uitgangspositie voor natuurontwikkeling.

- Recreatiesubsidie, voor het in stand houden van recreatievoorzieningen. Tegelijk met het vervallen van de openstellingstoeslag is het onderscheid tussen het 'lage' recreatiepakket $(14,27$ euro per ha in 2003) en 'hoge' recreatiepakket (24,46 euro per ha in 2003) verdwenen. $\mathrm{Er}$ is sinds 2004 één recreatiepakket dat in heel het land toepasbaar is, met een vergoeding van 33,34 euro per ha in 2012. Dit pakket kan niet worden afgesloten voor terreinen waarvoor een ontheffing van de openstellingsverplichting is verkregen.

Subsidieverordening Natuur- en Landschapsbeheer (SVNL)

Na 2012 vindt een (geleidelijke) overgang plaats van subsidiëring via het Programma Beheer naar subsidiëring via het Subsidiestelsel Natuur- en Landschap (SNL), onder de verantwoordelijkheid van de provincies. De 'Subsidieverordening Natuur- en Landschapsbeheer' (SVNL) binnen het SNL is gericht op het beheer van natuur en landschap. De modelverordening en -regeling worden jaarlijks door de gezamenlijke provincies bijgesteld en door de afzonderlijke provincies vastgesteld. Met behulp van de Index Natuur en Landschap worden de typen natuur, agrarische natuur en landschap in Nederland beschreven. De index is een gemeenschappelijke, landelijk uniforme 'natuurtaal'. De beheervergoeding in 2016 voor bijvoorbeeld het natuurtype 'Droog bos met productie' bedraagt 4,46 euro per ha, en die voor 'Vochtig bos met productie' 12,98 euro per ha.

\section{Subsidieregeling Kwaliteitsimpuls Natuur en Landschap (SKNL)}

Deze subsidieregeling binnen het Subsidiestelsel Natuur- en Landschap (SNL) is gericht op investeringen in natuur en landschap (omvorming, inrichting en kwaliteitsontwikkeling). Op basis van de SKNL kunnen Gedeputeerde Staten subsidie verstrekken voor eenmalige investeringen in bos- en natuurterreinen, met als doel de verhoging van de natuurkwaliteit van het bestaande natuurbeheertype of landschapsbeheertype, en de omzetting van een natuurterrein met een bepaald natuurbeheertype naar een ander gewenst natuurbeheertype. De hoogte van de subsidie bedraagt $95 \%$ van de goedgekeurde kosten. De provincies kunnen een maximumbedrag per hectare vaststellen. Een voorbeeld van kwaliteitsverbetering is het plaggen van een grotere oppervlakte heide om vergrassing tegen te gaan. De regeling voor kwaliteitsimpuls is in 2010 voor het eerst opengesteld.

\section{Jachthuur}

Daar elk bos een potentieel jachtgebied is, zijn de opbrengsten uit jachtverhuur in de exploitatierekening opgenomen. Indien de bossen niet voor de jacht zijn verhuurd, is ten behoeve van de wildregulatie het jachtgenot voor de eigenaar normatief als opbrengst opgenomen. Deze gegevens zijn vanaf 1981 bekend. Om een juiste vergelijking met de voorgaande jaren mogelijk te maken is deze opbrengst voor de voorliggende jaren normatief teruggerekend.

\section{Kerstbomen en -groen}

De verkopen van kerstbomen en -groen. Het betreft opbrengsten van kerstbomenuitdunningen, evenals de opbrengsten van een speciaal aangelegde kerstbomenkwekerij.

\section{Recreatie}

De recreatieopbrengsten bestaan onder meer uit de opbrengsten van een boscamping en natuur- en groepskampeerterreinen in het bos, excursies, entree-, vervoer- en parkeergelden, fietsverhuur, wandel-/fiets-/ruiterkaarten en visvergunningen. De berekende kosten voor verrichte werkzaamheden door vrijwilligers_(bijvoorbeeld ANWB, landgoedkampeerders, scouts) zijn ook als opbrengsten uit recreatie geboekt. 


\section{Overige bedrijfsopbrengsten}

De overige bedrijfsopbrengsten bestaan onder meer uit de verkoop van uitgangsmateriaal zoals plantsoen en zaden uit het bos, opstalrecht (ten behoeve van leidingen, zendmasten enzovoort), verhuur van bos aan derden (zoals hondenclubs, scouting, voor militaire oefeningen, rally's, crosscountry's enzovoort). Verder is hierin opgenomen de vergoeding voor schade aan het bos, zoals door brand, storm of ijzel- en sneeuwdruk.

\section{Incidentele nevenopbrengsten}

Ontvangen vergoedingen voor meestal eenmalig gebruik van (gedeeltelijke) bosterreinen, bijvoorbeeld voor slibberging, tijdelijke kerstbomenkwekerij enzovoort. Hieronder vallen ook de opbrengsten van overgenomen herplantplichten, plantrechtsafstand van laanbomen enzovoort.

\section{B1.3 Kosten}

\section{Loon eigen personeel}

Salaris, vakantie- en eindejaarsuitkering, sociale en overige toeslagen voor personeel met een vast arbeidscontract, ten behoeve van het terreinbeheer, en salariskosten van personeel zonder vast arbeidscontract (zoals uitzendkrachten, gedetacheerden, adviseurs), ten behoeve van het terreinbeheer.

\section{Berekende lonen}

Op normatieve wijze berekende loonkosten voor niet-betaalde bosarbeid. Deze arbeid kan zijn verricht door de eigenaar of diens familieleden, ANWB-landgoedkampeerders, scholieren, scouts, door de overheid gratis ter beschikking gestelde arbeidskrachten zoals WSW'ers enzovoort. Voor de eigenaar of diens familieleden is in 2017 een bedrag van 29,83 euro per uur opgenomen. Dit is afgeleid van het gemiddelde uurloon van een bosarbeider volgens de cao-bosbouw (inclusief de wettelijk verplichte sociale lasten). Voor de managementactiviteiten van de eigenaar (beheer, leiding en toezicht) wordt een hoger uurtarief aangehouden (36,38 euro). Voor de overige categorieën (vrijwilligers) is met 9,84 euro per uur gerekend, te weten genoemd cao-loon van de bosarbeider vermenigvuldigd met een reductiefactor voor geringere vakbekwaamheid en productiviteit.

\section{Werk door derden}

De kosten voor het terreinbeheer die door derden in rekening worden gebracht, zoals de bosgroep, rentmeester, ingenieursbureau, loonwerker en een collega-natuurbeheerder. Niet opgenomen in deze post zijn de oogstkosten voor op stam verkocht hout, zowel uit dunning als eindkap. De kosten daarvan zijn in een lagere prijs per verkochte kubieke meter hout tot uiting gebracht. Onder werk door derden vallen ook de kosten van arbeid in het kader van de diverse werkgelegenheidsregelingen. De betreffende overheidsbijdrage is opgenomen onder de post 'Subsidies en bijdragen'.

\section{Machines, werktuigen en auto's}

De waarde van de machines, werktuigen en auto's die worden gebruikt voor het bosbeheer worden in samenspraak met de deelnemer getaxeerd. De afschrijving en rente worden berekend conform de methodiek van Wageningen Economic Research voor land- en tuinbouw. Er is gerekend met een standaardrentepercentage over het gemiddeld geïnvesteerd vermogen (het gemiddelde van de waarde op de begin- en eindbalans) in machines, werktuigen en auto's. De overige kosten van machines, werktuigen en auto's bestaan onder meer uit kosten voor onderhoud, reparatie, brandstof en verzekeringen, evenals de vergoeding (28 eurocent per kilometer) voor de door de eigenaar met zijn privéauto verreden kilometers ten behoeve van het bosbedrijf.

Grond- en hulpstoffen

Kosten voor aangekocht zaaizaad, plantsoen, meststoffen en bestrijdingsmiddelen. De overige materialen bestaan voornamelijk uit materialen ten behoeve van wegverharding, afrasteringen, duikers enzovoort. 


\section{Heffingen en verzekeringen}

Op de bossen drukkende waterschapslasten en heffingen opgelegd door het Bosschap. Met het einde van de publiekrechtelijke bedrijfsorganisatie zijn de heffingen van het Bosschap na 2014 vervallen. Indien de bossen geheel of gedeeltelijk zijn verzekerd tegen bosbrand dan wel stormschade, behoort de verschuldigde premie tot deze kostencategorie.

\section{Overige bedrijfskosten}

Over het in grond en houtopstand geïnvesteerde vermogen wordt geen rente in rekening gebracht. De berekening van de rente en afschrijvingskosten van gebouwen (inclusief kantoor) die in gebruik zijn voor het bosbeheer is conform die voor machines, werktuigen en auto's. Voorts zijn er de overige kosten voor gebouwen (en kantoren) die in gebruik zijn voor het bosbeheer, zoals verzekeringen en onderhoud, kantoormateriaal, telecommunicatie en energie/water. Ook worden in deze post meegenomen: de betaalde contributies, abonnementen op vakbladen, betaalde pensioenen aan oudbosarbeiders of hun weduwen, representatiekosten en de premie voor de bedrijfs-WA-verzekering.

\section{B1.4 Kostenplaatsen}

De diverse kostensoorten kunnen worden toegerekend naar kostenplaatsen, ook wel aangeduid met maatregelen of activiteiten. Deze zijn ingedeeld naar een aantal hoofdgroepen.

\section{Algemeen bosbeheer}

De algemene kosten hebben betrekking op beheer, leiding en toezicht, heffingen en verzekeringen, en overige algemene kosten (niet toe te rekenen aan activiteiten).

Onder beheer, leiding en toezicht vallen onder andere het plannen, begroten en opstellen van beheeren werkplannen, het uitbesteden en organiseren van werkzaamheden, het aanvragen van subsidies, de verkoop van hout, onderzoek en monitoring, en het toezicht op de uitvoering van werkzaamheden en de dagelijkse gang van zaken in het bos, inclusief toezicht op recreanten. De kosten voor deze activiteiten bestaan uit (berekende) lonen en betaalde kosten voor bijvoorbeeld een rentmeester, bosgroep en ingenieursbureau.

\section{Bosverjonging}

Kosten voor bodembewerking, plantwerkzaamheden voor (her)bebossing en inboetwerkzaamheden.

\section{Bosonderhoud}

De activiteiten jeugdverzorging (vrijstellen en zuiveren), opkronen, prunusbestrijding (of andere ongewenste houtopslag), onrendabele dunning (stamtaalreductie zonder ontvangsten) en het aanwijzen van toekomstbomen.

\section{Infrastructuur}

Kosten voor werkzaamheden en materialen ten behoeve van wegen, paden, waterlopen, hekken, rasters en recreatieve voorzieningen.

\section{Houtoogst (vellingen)}

Deze kosten bestaan uit arbeidskosten, werk door derden en werktuigkosten (voor zover gemaakt bij zelf uitgevoerde dunningen en kaalslagen). Met ingang van 1997 is de post 'Blessen en meten uit beheer en leiding' geplaatst onder de post 'Houtoogst'. Het betreft de kosten voor het blessen van de te vellen bomen bij een dunning, evenals het meten van het gevelde hout (zowel dunning als eindkap). Bijna altijd vindt dit plaats bij zowel op stam als geveld verkocht hout. 


\section{Bijlage 2 Tabellen}

\section{B2.1 Bedrijfsresultaten per hectare}

Tabel B2.1 Bedrijfsresultaat (euro per ha bos) particuliere bosbedrijven, 2013-2017

\begin{tabular}{|c|c|c|c|c|c|c|}
\hline Kosten & 2013 & 2014 & 2015 & 2016 & 2017 & Gemiddeld \\
\hline \multicolumn{7}{|l|}{ Arbeid (uitvoerend) } \\
\hline loon eigen personeel & 39 & 39 & 38 & 38 & 44 & 40 \\
\hline berekend loon & 31 & 31 & 35 & 38 & 40 & 35 \\
\hline totaal & 71 & 71 & 73 & 76 & 84 & 75 \\
\hline \multicolumn{7}{|l|}{ Beheer, leiding en toezicht } \\
\hline beheer en leiding & 58 & 52 & 56 & 56 & 61 & 57 \\
\hline toezicht & 26 & 26 & 29 & 27 & 31 & 28 \\
\hline blessen en meten (arbeid) & 2 & 2 & 1 & 1 & 1 & 1 \\
\hline blessen en meten (loonwerk) & 4 & 5 & 5 & 6 & 5 & 5 \\
\hline totaal & 90 & 85 & 91 & 90 & 98 & 91 \\
\hline \multicolumn{7}{|l|}{ Werk door derden } \\
\hline (her)bebossing & 7 & 5 & 4 & 8 & 12 & 7 \\
\hline bosonderhoud & 23 & 32 & 27 & 26 & 28 & 27 \\
\hline houtoogst & 16 & 6 & 9 & 13 & 14 & 12 \\
\hline infrastructuur & 10 & 10 & 14 & 9 & 13 & 11 \\
\hline totaal & 56 & 52 & 53 & 55 & 66 & 56 \\
\hline Werktuigen & 21 & 23 & 24 & 24 & 25 & 23 \\
\hline Grond- en hulpstoffen & 11 & 11 & 7 & 12 & 11 & 10 \\
\hline \multicolumn{7}{|l|}{ Grond en houtopstand } \\
\hline waterschapslasten & 4 & 4 & 4 & 4 & 4 & 4 \\
\hline heffing Bosschap & 3 & 3 & 0 & 0 & 0 & 1 \\
\hline bosbrandverzekering & 4 & 4 & 3 & 4 & 4 & 4 \\
\hline totaal & 12 & 11 & 8 & 8 & 8 & 9 \\
\hline Overige bedrijfskosten & 20 & 20 & 23 & 24 & 23 & 22 \\
\hline Totaal exploitatiekosten & 281 & 273 & 279 & 289 & 315 & 287 \\
\hline Positief bedrijfsresultaat & 24 & 39 & 14 & & & 15 \\
\hline Totaal & 305 & 312 & 293 & 289 & 315 & 303 \\
\hline
\end{tabular}

Tabel B2.1 (vervolg) Bedrijfsresultaat (euro per ha bos) particuliere bosbedrijven, 2013-2017

\begin{tabular}{|c|c|c|c|c|c|c|}
\hline Opbrengsten & 2013 & 2014 & 2015 & 2016 & 2017 & Gemiddeld \\
\hline \multicolumn{7}{|l|}{ Houtopbrengsten } \\
\hline op stam verkocht & 133 & 132 & 120 & 101 & 90 & 115 \\
\hline geveld verkocht & 11 & 10 & 11 & 14 & 14 & 12 \\
\hline overige houtopbrengsten & 6 & 7 & 6 & 9 & 9 & 7 \\
\hline totaal houtopbrengsten & 149 & 149 & 137 & 123 & 112 & 134 \\
\hline \multicolumn{7}{|l|}{ Overig bedrijfsopbrengsten } \\
\hline jachthuur & 13 & 14 & 15 & 15 & 15 & 14 \\
\hline kerstbomen en -groen & 5 & 5 & 4 & 7 & 6 & 5 \\
\hline recreatie & 29 & 29 & 32 & 32 & 30 & 30 \\
\hline overige & 11 & 16 & 23 & 15 & 14 & 16 \\
\hline totaal & 57 & 64 & 74 & 68 & 65 & 66 \\
\hline Incidentele opbrengsten & 0 & 1 & 0 & 1 & 1 & 1 \\
\hline \multicolumn{7}{|l|}{ Subsidies en bijdragen } \\
\hline beheersubsidie & 81 & 74 & 72 & 73 & 73 & 75 \\
\hline overige & 17 & 24 & 9 & 15 & 22 & 17 \\
\hline totaal & 98 & 98 & 81 & 88 & 94 & 92 \\
\hline Totaal bedrijfsopbrengsten & 305 & 312 & 293 & 281 & 271 & 292 \\
\hline Negatief bedrijfsresultaat & & & & 8 & 44 & 10 \\
\hline Totaal & 305 & 312 & 293 & 289 & 315 & 303 \\
\hline
\end{tabular}


Tabel B2.2 Bedrijfsresultaat (euro per ha bos) particuliere bosbedrijven naar bosareaal in ha, 2017

\begin{tabular}{|c|c|c|c|c|c|c|c|}
\hline Kosten & $5-25$ & $25-50$ & $50-100$ & $100-250$ & $\geq 250$ & $\begin{array}{r}\text { Totaal } \\
2017\end{array}$ & $\begin{array}{r}\text { Totaal } \\
2016\end{array}$ \\
\hline \multicolumn{8}{|l|}{ Arbeid } \\
\hline loon eigen personeel & 55 & 7 & 85 & 87 & 87 & 71 & 65 \\
\hline diverse berekende Ionen & 262 & 71 & 35 & 37 & 8 & 71 & 65 \\
\hline totaal & 317 & 78 & 120 & 124 & 95 & 141 & 131 \\
\hline \multicolumn{8}{|l|}{ Werk door derden } \\
\hline loonwerker & 56 & 41 & 134 & 64 & 45 & 62 & 55 \\
\hline rentmeester en overig & 48 & 55 & 73 & 55 & 26 & 45 & 36 \\
\hline totaal & 103 & 97 & 208 & 119 & 72 & 108 & 91 \\
\hline \multicolumn{8}{|l|}{ Werktuigen } \\
\hline rente en afschrijving & 17 & 5 & 5 & 10 & 6 & 8 & 8 \\
\hline overige werktuigkosten & 23 & 8 & 27 & 12 & 14 & 16 & 16 \\
\hline totaal & 40 & 13 & 32 & 22 & 20 & 25 & 24 \\
\hline \multicolumn{8}{|l|}{ Grond- en hulpstoffen } \\
\hline plantsoen en zaad & 6 & 4 & 6 & 5 & 5 & 5 & 8 \\
\hline mest-/bestrijdingsmiddelen & 0 & 0 & 0 & 0 & 0 & 0 & 0 \\
\hline overige grond-/hulpstoffen & 12 & 1 & 1 & 6 & 5 & 6 & 4 \\
\hline totaal & 18 & 5 & 8 & 12 & 10 & 11 & 12 \\
\hline \multicolumn{8}{|l|}{ Bosinstandhouding } \\
\hline gebouwen en infrastructuur & 21 & 0 & 2 & 1 & 1 & 4 & 5 \\
\hline grond/waterschapslasten & 4 & 6 & 4 & 5 & 4 & 4 & 4 \\
\hline heffing bosschap & 0 & 0 & 0 & 0 & 0 & 0 & 0 \\
\hline bosbrandverzekering & 5 & 5 & 5 & 5 & 2 & 4 & 4 \\
\hline totaal & 31 & 11 & 11 & 10 & 7 & 13 & 13 \\
\hline Overige bedrijfskosten & 30 & 18 & 14 & 21 & 13 & 18 & 19 \\
\hline Totaal exploitatiekosten & 539 & 221 & 393 & 309 & 216 & 315 & 289 \\
\hline Positief bedrijfsresultaat & & & & 52 & 15 & & \\
\hline Totaal & 539 & 221 & 393 & 361 & 231 & 315 & 289 \\
\hline
\end{tabular}

Tabel B2.2 (vervolg) Bedriffsresultaat (euro per ha bos) particuliere bosbedrijven naar bosareaal in ha, 2017

\begin{tabular}{|c|c|c|c|c|c|c|c|}
\hline Opbrengsten & $5-25$ & $25-50$ & $50-100$ & $100-250$ & $\geq 250$ & $\begin{array}{r}\text { Totaal } \\
2017\end{array}$ & $\begin{array}{r}\text { Totaal } \\
2016\end{array}$ \\
\hline \multicolumn{8}{|l|}{ Houtopbrengsten } \\
\hline op stam & 47 & 35 & 124 & 164 & 84 & 90 & 101 \\
\hline geveld & 40 & 18 & 3 & 3 & 8 & 14 & 14 \\
\hline overige houtopbrengsten & 10 & 4 & 20 & 10 & 5 & 9 & 9 \\
\hline totaal & 96 & 58 & 147 & 178 & 98 & 112 & 123 \\
\hline \multicolumn{8}{|l|}{ Overige bedrijfsopbrengsten } \\
\hline jachthuur & 12 & 8 & 11 & 18 & 18 & 15 & 15 \\
\hline kerstbomen en -groen & 31 & 0 & 0 & 1 & 0 & 6 & 7 \\
\hline recreatie, boscamping & 37 & 0 & 0 & 1 & 4 & 8 & 8 \\
\hline recreatie, overig & 70 & 11 & 18 & 11 & 7 & 21 & 23 \\
\hline overige & 31 & 18 & 5 & 8 & 11 & 14 & 15 \\
\hline totaal & 181 & 37 & 34 & 38 & 41 & 65 & 68 \\
\hline Incidentele opbrengsten & 0 & 0 & 0 & 5 & 0 & 1 & 1 \\
\hline \multicolumn{8}{|l|}{ Subsidies en bijdragen } \\
\hline beheersubsidie & 57 & 73 & 62 & 113 & 67 & 73 & 73 \\
\hline overige subsidies & 12 & 2 & 36 & 0 & 25 & 22 & 15 \\
\hline totaal & 69 & 75 & 98 & 29 & 92 & 94 & 88 \\
\hline Totaal bedrijfsopbrengsten & 347 & 170 & 279 & 361 & 231 & 271 & 281 \\
\hline Negatief bedrijfsresultaat & 193 & 52 & 114 & & & 44 & 8 \\
\hline Totaal & 537 & 221 & 393 & 361 & 231 & 315 & 289 \\
\hline
\end{tabular}


Tabel B2.3 Bedrijfsresultaten (euro per ha bos) alle bedrijven naar regio, 2017

\begin{tabular}{|c|c|c|c|c|c|}
\hline Kosten & Noordoost & Centrum & Zuid & Totaal 2017 & Totaal 2016 \\
\hline \multicolumn{6}{|l|}{ Arbeid } \\
\hline Ioon eigen personeel & 63 & 114 & 31 & 71 & 65 \\
\hline totaal & 136 & 219 & 56 & 141 & 131 \\
\hline \multicolumn{6}{|l|}{ Werk door derden } \\
\hline totaal & 108 & 141 & 66 & 108 & 91 \\
\hline \multicolumn{6}{|l|}{ Werktuigen } \\
\hline rente en afschrijving & 12 & 9 & 2 & 8 & 8 \\
\hline overige werktuigkosten & 15 & 26 & 8 & 16 & 16 \\
\hline mest- en bestrijdingsmiddelen & 0 & 0 & 0 & 0 & 0 \\
\hline overige grond- en hulpstoffen & 3 & 13 & 1 & 6 & 4 \\
\hline totaal & 11 & 19 & 2 & 11 & 12 \\
\hline \multicolumn{6}{|l|}{ Bosinstandhouding } \\
\hline gebouwen en infrastructuur & 1 & 13 & 0 & 4 & 5 \\
\hline grond-/waterschapslasten & 5 & 4 & 3 & 4 & 4 \\
\hline heffing bosschap & 0 & 0 & 0 & 0 & 0 \\
\hline bosbrandverzekering & 3 & 5 & 3 & 4 & 4 \\
\hline totaal & 9 & 23 & 6 & 13 & 13 \\
\hline
\end{tabular}

Tabel B2.3 (vervolg) Bedrijfsresultaten (euro per ha bos) alle bedrijven naar regio, 2017

\begin{tabular}{|c|c|c|c|c|c|}
\hline Opbrengsten & Noordoost & Centrum & Zuid & Totaal 2017 & Totaal 2016 \\
\hline \multicolumn{6}{|l|}{ Houtopbrengsten } \\
\hline op stam & 115 & 88 & 49 & 90 & 101 \\
\hline overige houtopbrengsten & 12 & 11 & 1 & 9 & 9 \\
\hline totaal & 146 & 114 & 52 & 112 & 123 \\
\hline kerstbomen en -groen & 0 & 18 & 0 & 6 & 7 \\
\hline recreatie, boscamping & 4 & 22 & 0 & 8 & 8 \\
\hline recreatie, overige opbrengst & 8 & 53 & 6 & 21 & 23 \\
\hline overige & 11 & 31 & 1 & 14 & 15 \\
\hline beheersubsidie & 75 & 77 & 64 & 73 & 73 \\
\hline overige subsidies & 35 & 21 & 1 & 22 & 15 \\
\hline totaal & 109 & 98 & 65 & 94 & 88 \\
\hline Totaal bedrijfsopbrengsten & 288 & 360 & 139 & 271 & 281 \\
\hline Negatief bedrijfsresultaat & 20 & 104 & 11 & 44 & 8 \\
\hline Totaal & 308 & 464 & 150 & 315 & 289 \\
\hline
\end{tabular}


Tabel B2.4 Kosten arbeid en loonwerk (euro per ha bos) particuliere bosbedrijven naar omvang bosareaal in ha, 2017

\begin{tabular}{|c|c|c|c|c|c|c|c|}
\hline Kosten & $5-25$ & $25-50$ & $50-100$ & $100-250$ & $\geq 250$ & $\begin{array}{r}\text { Totaal } \\
2017\end{array}$ & $\begin{array}{r}\text { Totaal } \\
2016\end{array}$ \\
\hline \multicolumn{8}{|c|}{ Arbeid, betaald loon eigen personeel } \\
\hline beheer en leiding & 5 & 1 & 10 & 19 & 22 & 14 & 15 \\
\hline toezicht & 3 & 4 & 7 & 21 & 17 & 12 & 12 \\
\hline bosverjonging & 2 & 0 & 0 & 7 & 5 & 4 & 4 \\
\hline bosverzorging & 33 & 0 & 48 & 26 & 31 & 29 & 25 \\
\hline houtoogst & 0 & 1 & 0 & 6 & 5 & 3 & 2 \\
\hline infrastructuur & 12 & 1 & 20 & 8 & 7 & 9 & 8 \\
\hline totaal & 55 & 7 & 85 & 87 & 87 & 71 & 65 \\
\hline \multicolumn{8}{|l|}{ Arbeid, berekend loon } \\
\hline beheer en leiding & 50 & 17 & 10 & 19 & 3 & 17 & 16 \\
\hline toezicht & 47 & 17 & 7 & 6 & 1 & 13 & 12 \\
\hline bosverjonging & 2 & 1 & 1 & 0 & 0 & 1 & 1 \\
\hline bosverzorging & 96 & 22 & 13 & 9 & 4 & 25 & 24 \\
\hline houtoogst & 22 & 10 & 2 & 1 & 0 & 6 & 5 \\
\hline infrastructuur & 46 & 3 & 1 & 1 & 0 & 9 & 8 \\
\hline totaal & 262 & 71 & 35 & 37 & 8 & 71 & 65 \\
\hline \multicolumn{8}{|l|}{ Loonwerk } \\
\hline beheer en leiding & 24 & 31 & 59 & 48 & 16 & 31 & 26 \\
\hline toezicht & 18 & 2 & 8 & 5 & 1 & 6 & 4 \\
\hline bosverjonging & 13 & 6 & 36 & 6 & 6 & 12 & 8 \\
\hline bosverzorging & 23 & 40 & 29 & 28 & 25 & 28 & 26 \\
\hline houtoogst & 18 & 12 & 45 & 13 & 14 & 18 & 19 \\
\hline infrastructuur & 6 & 6 & 31 & 19 & 9 & 13 & 9 \\
\hline totaal & 103 & 97 & 208 & 119 & 72 & 107 & 91 \\
\hline Overige kosten & 119 & 47 & 65 & 66 & 49 & 66 & 67 \\
\hline Totaal & 539 & 221 & 393 & 309 & 216 & 315 & 289 \\
\hline
\end{tabular}

Tabel B2.5 Kosten arbeid en loonwerk (euro per ha bos) particuliere bosbedrijven naar regio, 2017

\begin{tabular}{|c|c|c|c|c|c|}
\hline Kosten & Noordoost & Centrum & Zuid & Totaal 2017 & Totaal 2016 \\
\hline \multicolumn{6}{|c|}{ Arbeid, betaald loon eigen personeel } \\
\hline beheer en leiding & 15 & 12 & 13 & 14 & 15 \\
\hline toezicht & 12 & 13 & 13 & 12 & 12 \\
\hline bosverjonging & 7 & 2 & 0 & 4 & 4 \\
\hline bosverzorging & 16 & 68 & 4 & 29 & 25 \\
\hline houtoogst & 6 & 1 & 0 & 3 & 2 \\
\hline infrastructuur & 7 & 19 & 1 & 9 & 8 \\
\hline totaal & 63 & 114 & 31 & 71 & 65 \\
\hline \multicolumn{6}{|l|}{ Arbeid, berekend loon } \\
\hline beheer en leiding & 19 & 21 & 7 & 17 & 16 \\
\hline toezicht & 17 & 11 & 10 & 13 & 12 \\
\hline bosverjonging & 0 & 1 & 1 & 1 & 1 \\
\hline bosverzorging & 15 & 56 & 4 & 25 & 24 \\
\hline houtoogst & 11 & 3 & 3 & 6 & 5 \\
\hline infrastructuur & 11 & 12 & 2 & 9 & 8 \\
\hline totaal & 73 & 105 & 25 & 71 & 65 \\
\hline \multicolumn{6}{|l|}{ Loonwerk } \\
\hline beheer en leiding & 30 & 35 & 27 & 31 & 26 \\
\hline toezicht & 1 & 9 & 10 & 6 & 4 \\
\hline bosverjonging & 7 & 24 & 6 & 12 & 8 \\
\hline bosverzorging & 29 & 38 & 14 & 28 & 26 \\
\hline houtoogst & 33 & 12 & 2 & 18 & 19 \\
\hline infrastructuur & 9 & 23 & 7 & 13 & 9 \\
\hline totaal & 108 & 141 & 66 & 107 & 91 \\
\hline Overige kosten & 63 & 104 & 28 & 66 & 67 \\
\hline Totaal & 308 & 464 & 150 & 315 & 289 \\
\hline
\end{tabular}


Tabel B2.6 Bedrijfsresultaten (euro per ha bos) particuliere bosbedrijven groter dan 50 ha, 2013-2017

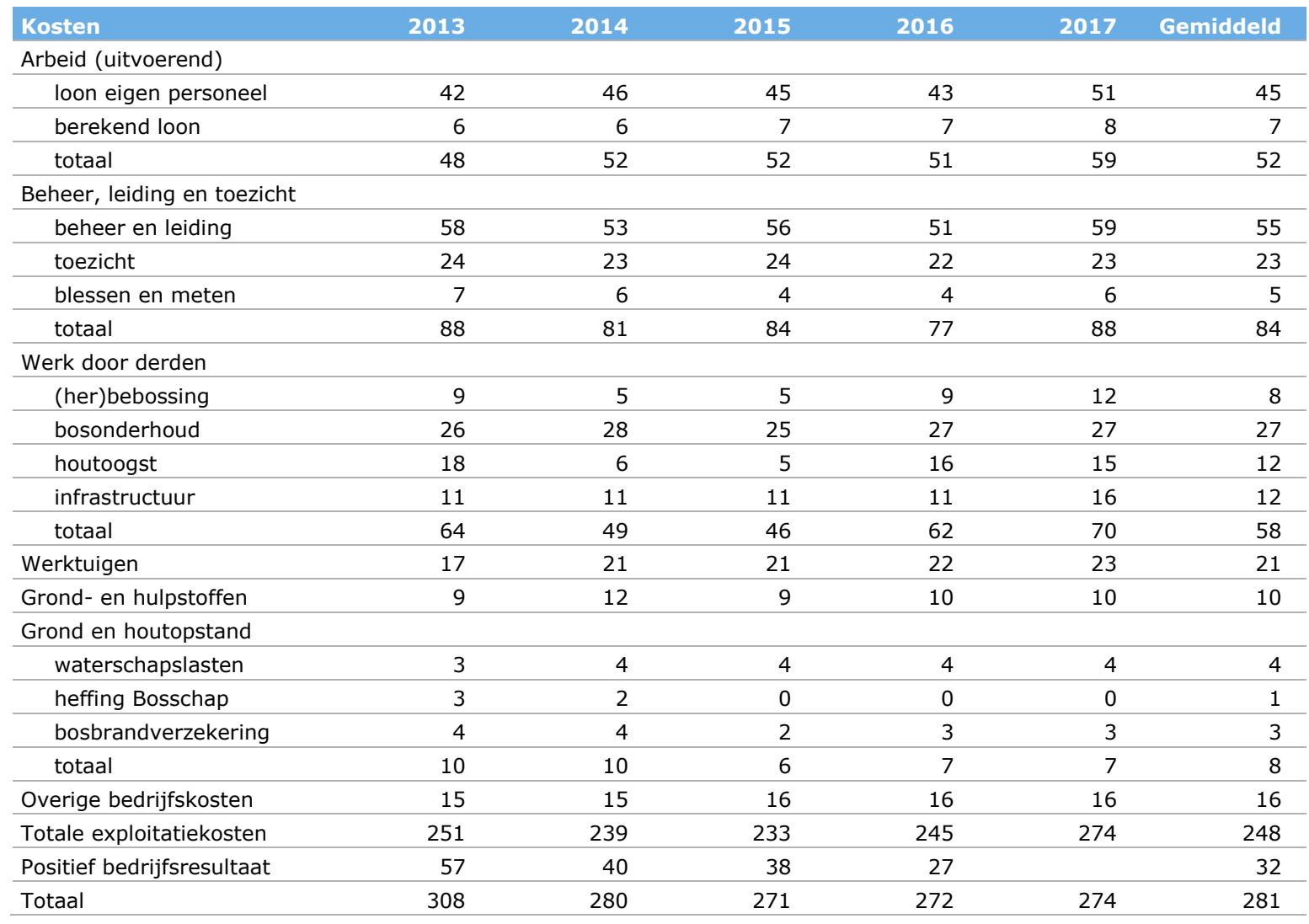

Tabel B2.6 (vervolg) Bedrijfsresultaten (euro per ha bos) particuliere bosbedrijven groter dan 50 ha, 2013-2017

\begin{tabular}{|c|c|c|c|c|c|c|}
\hline Opbrengsten & 2013 & 2014 & 2015 & 2016 & 2017 & Gemiddeld \\
\hline \multicolumn{7}{|l|}{ Houtopbrengsten } \\
\hline op stam verkocht & 150 & 121 & 114 & 116 & 111 & 122 \\
\hline overige houtopbrengsten & 6 & 7 & 7 & 8 & 9 & 7 \\
\hline totaal houtopbrengsten & 161 & 136 & 129 & 136 & 126 & 138 \\
\hline kerstbomen en -groen & 0 & 0 & 0 & 0 & 0 & 0 \\
\hline recreatie & 14 & 15 & 15 & 15 & 13 & 14 \\
\hline overige & 8 & 12 & 21 & 9 & 9 & 12 \\
\hline totaal & 38 & 45 & 54 & 41 & 39 & 43 \\
\hline overige & 22 & 15 & 10 & 16 & 28 & 18 \\
\hline totaal & 109 & 96 & 87 & 93 & 105 & 98 \\
\hline Totale bedrijfsopbrengsten & 308 & 280 & 271 & 272 & 271 & 280 \\
\hline Negatief bedrijfsresultaat & & & & & 3 & 1 \\
\hline Totaal & 308 & 280 & 271 & 272 & 274 & 281 \\
\hline
\end{tabular}


Tabel B2.7 Bedrijfsresultaten (euro per ha bos) particuliere bosbedrijven groter dan 50 ha naar regio, 2017

\begin{tabular}{|c|c|c|c|c|c|}
\hline Kosten & Noordoost & Centrum & Zuid & Totaal 2017 & Totaal 2016 \\
\hline \multicolumn{6}{|l|}{ Arbeid } \\
\hline Ioon eigen personeel & 91 & 110 & 46 & 87 & 78 \\
\hline totaal & 114 & 127 & 65 & 107 & 97 \\
\hline \multicolumn{6}{|l|}{ Werk door derden } \\
\hline totaal & 115 & 138 & 65 & 111 & 93 \\
\hline \multicolumn{6}{|l|}{ Werktuigen } \\
\hline rente en afschrijving & 11 & 4 & 2 & 7 & 6 \\
\hline overige werktuigkosten & 14 & 22 & 11 & 16 & 15 \\
\hline mest en bestrijdingsmiddel & 0 & 0 & 0 & 0 & 0 \\
\hline overige grond- en hulpstoffen & 4 & 8 & 1 & 5 & 5 \\
\hline totaal & 14 & 11 & 2 & 10 & 10 \\
\hline \multicolumn{6}{|l|}{ Bosinstandhouding } \\
\hline gebouwen en infrastructuur & 2 & 1 & 0 & 1 & 1 \\
\hline grond-/waterschapslasten & 5 & 3 & 3 & 4 & 4 \\
\hline heffing bosschap & 0 & 0 & 0 & 0 & 0 \\
\hline bosbrandverzekering & 3 & 4 & 4 & 3 & 3 \\
\hline totaal & 10 & 7 & 7 & 8 & 8 \\
\hline Overige bedrijfskosten & 15 & 19 & 10 & 15 & 15 \\
\hline
\end{tabular}

Tabel B2.7 (vervolg) Bedrijfsresultaten (euro per ha bos) particuliere bosbedrijven groter dan 50 ha naar regio, 2017

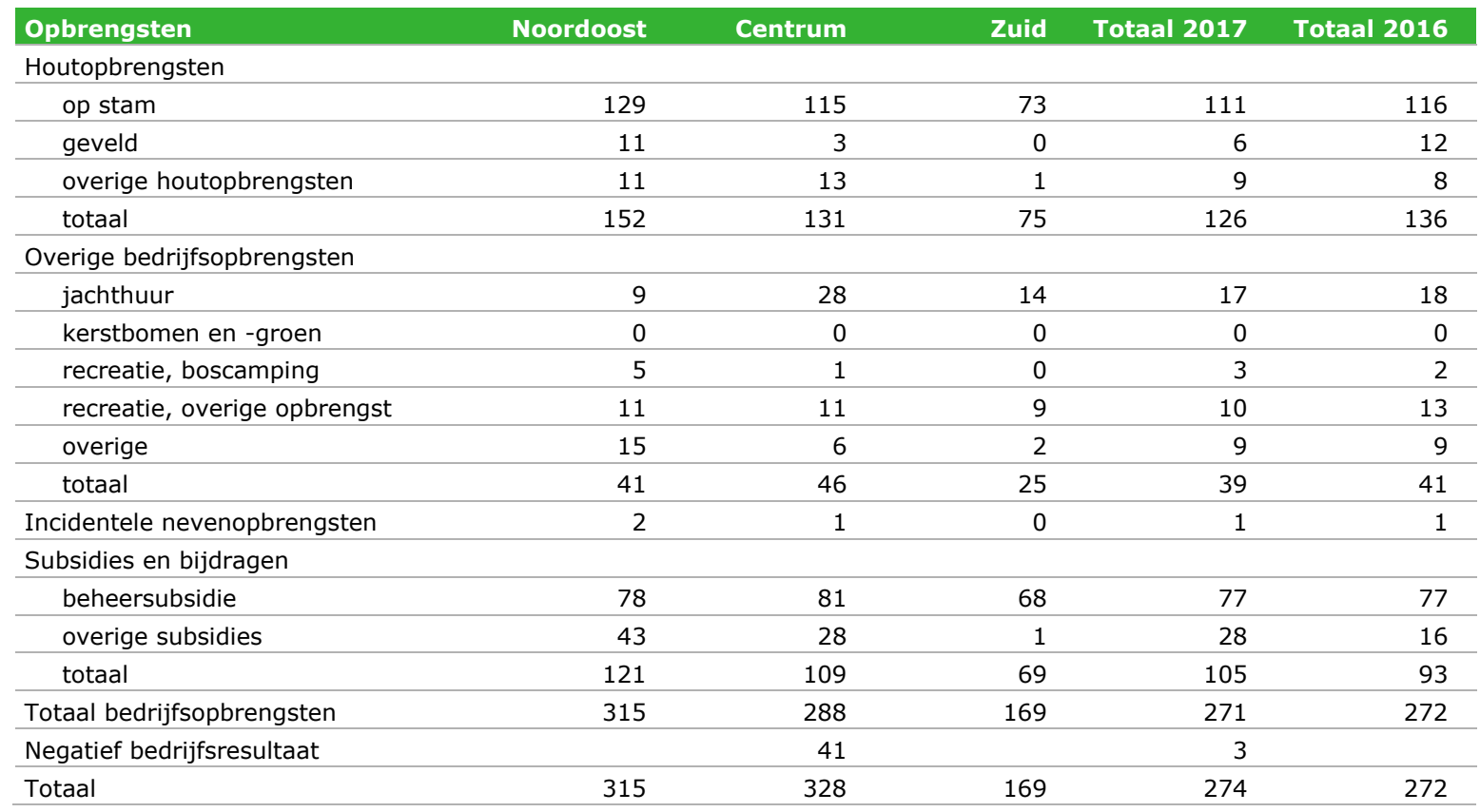


Tabel B2.8 Kosten arbeid en loonwerk (euro per ha bos) particuliere bosbedrijven groter dan 50 ha naar regio, 2017

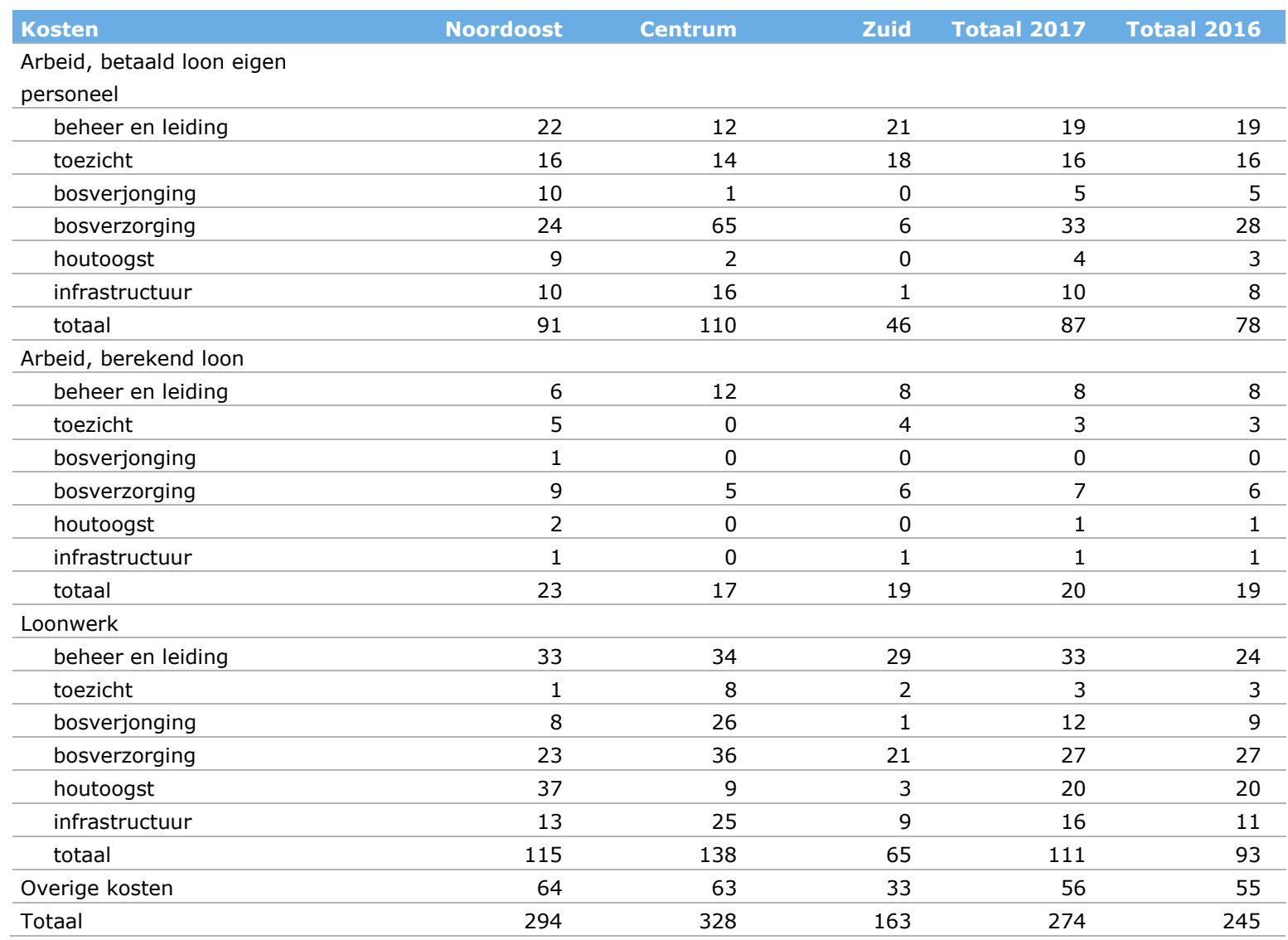




\section{B2.2 Kosten naar kostenplaatsen}

Tabel B2.9 Kosten (euro per ha bos) alle bedrijven naar kostenplaats en omvang bosareaal in ha, 2017

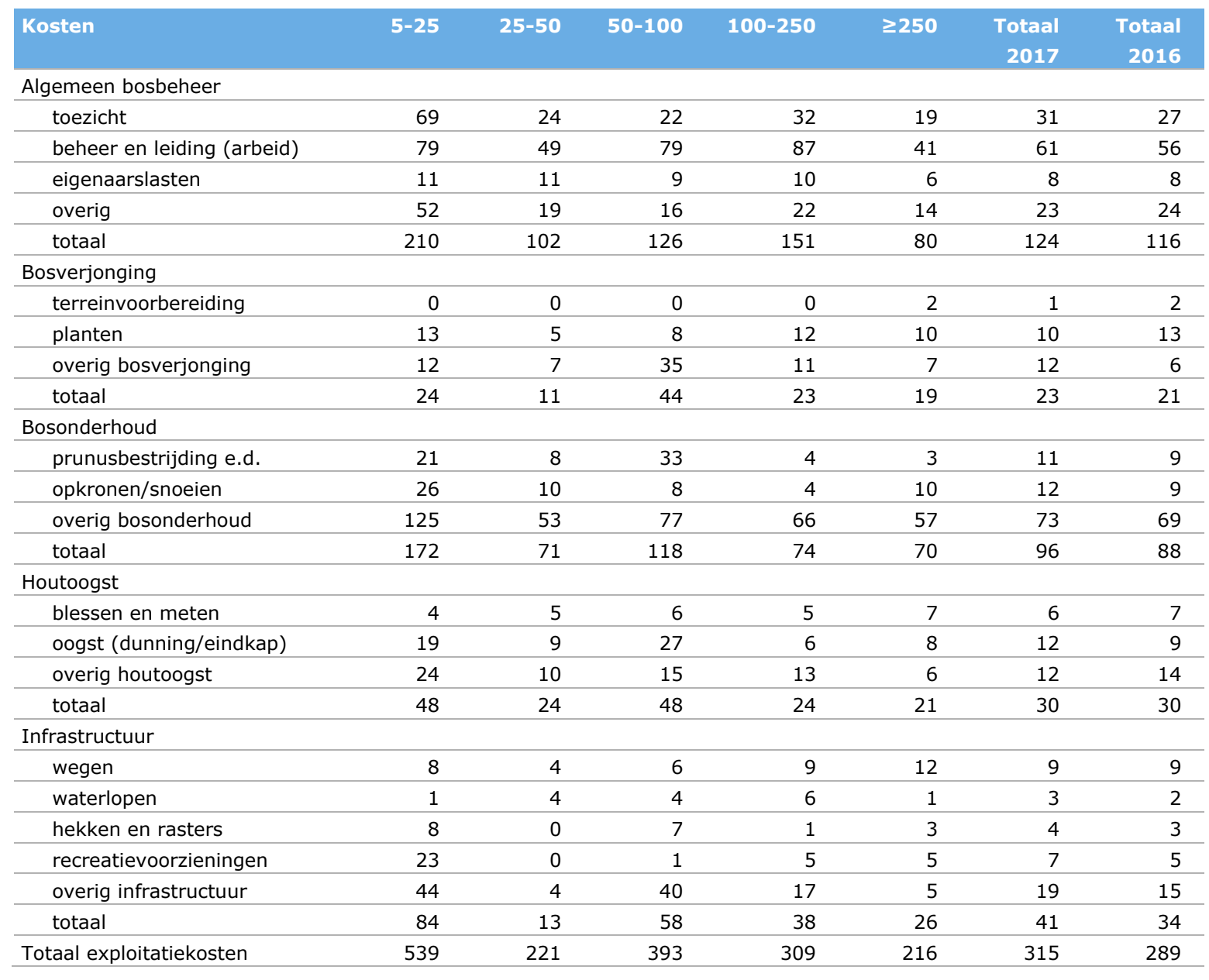


Tabel B2.10 Kosten (euro per ha bos) alle bedrijven naar kostenplaats en regio, 2017

\begin{tabular}{|c|c|c|c|c|c|}
\hline Kosten & Noordoost & Centrum & Zuid & Totaal 2017 & Totaal 2016 \\
\hline \multicolumn{6}{|l|}{ Algemeen bosbeheer } \\
\hline toezicht & 29 & 33 & 32 & 31 & 27 \\
\hline eigenaarslasten & 8 & 10 & 6 & 8 & 8 \\
\hline overig & 19 & 40 & 10 & 23 & 24 \\
\hline totaal & 122 & 152 & 96 & 124 & 116 \\
\hline terreinvoorbereiding & 1 & 0 & 1 & 1 & 2 \\
\hline planten & 13 & 13 & 2 & 10 & 13 \\
\hline overig bosverjonging & 10 & 22 & 5 & 12 & 6 \\
\hline totaal & 24 & 35 & 8 & 23 & 21 \\
\hline totaal & 72 & 186 & 30 & 96 & 88 \\
\hline \multicolumn{6}{|l|}{ Houtoogst } \\
\hline blessen en meten & 8 & 6 & 1 & 6 & 7 \\
\hline oogst (dunning/eindkap) & 25 & 4 & 1 & 12 & 9 \\
\hline overig houtoogst & 21 & 9 & 1 & 12 & 14 \\
\hline totaal & 55 & 18 & 3 & 30 & 30 \\
\hline \multicolumn{6}{|l|}{ Infrastructuur } \\
\hline wegen & 10 & 9 & 5 & 9 & 9 \\
\hline waterlopen & 3 & 4 & 1 & 3 & 2 \\
\hline
\end{tabular}


Tabel B2.11 Kosten (euro per ha bos) particuliere bosbedrijven groter dan 50 ha naar kostenplaats en regio, 2017

\begin{tabular}{|c|c|c|c|c|c|}
\hline Kosten & Noordoost & Centrum & Zuid & Totaal 2017 & Totaal 2016 \\
\hline \multicolumn{6}{|l|}{ Algemeen bosbeheer } \\
\hline toezicht & 22 & 23 & 24 & 23 & 22 \\
\hline beheer en leiding (arbeid) & 62 & 57 & 58 & 59 & 51 \\
\hline eigenaarslasten & 8 & 7 & 7 & 7 & 7 \\
\hline overig & 17 & 20 & 10 & 16 & 16 \\
\hline totaal & 109 & 107 & 99 & 106 & 96 \\
\hline \multicolumn{6}{|l|}{ Bosverjonging } \\
\hline terreinvoorbereiding & 2 & 0 & 2 & 1 & 3 \\
\hline planten & 17 & 7 & 2 & 10 & 11 \\
\hline overig bosverjonging & 13 & 25 & 0 & 14 & 7 \\
\hline totaal & 32 & 32 & 4 & 25 & 22 \\
\hline \multicolumn{6}{|l|}{ Bosonderhoud } \\
\hline prunusbestrijding e.d. & 12 & 11 & 3 & 10 & 7 \\
\hline opkronen/snoeien & 7 & 9 & 9 & 8 & 7 \\
\hline overig bosonderhoud & 50 & 104 & 31 & 63 & 58 \\
\hline totaal & 69 & 124 & 43 & 81 & 72 \\
\hline \multicolumn{6}{|l|}{ Houtoogst } \\
\hline blessen en meten & 10 & 6 & 1 & 6 & 4 \\
\hline oogst (dunning/eindkap) & 25 & 1 & 2 & 11 & 8 \\
\hline overig houtoogst & 16 & 6 & 1 & 9 & 15 \\
\hline totaal & 51 & 12 & 4 & 27 & 27 \\
\hline \multicolumn{6}{|l|}{ Infrastructuur } \\
\hline wegen & 15 & 7 & 4 & 10 & 11 \\
\hline waterlopen & 4 & 3 & 1 & 3 & 2 \\
\hline hekken en rasters & 3 & 6 & 0 & 3 & 3 \\
\hline recreatieve voorzieningen & 4 & 6 & 0 & 4 & 2 \\
\hline overig infrastructuur & 6 & 31 & 9 & 15 & 11 \\
\hline totaal & 33 & 53 & 14 & 35 & 29 \\
\hline Totaal exploitatiekosten & 294 & 328 & 163 & 274 & 245 \\
\hline
\end{tabular}




\section{B2.3 Houtoogst en opbrengstprijzen}

Tabel B2.12 Houtoogst ( $m^{3}$ per ha bos) naar omvang bos in ha, 1989-2017

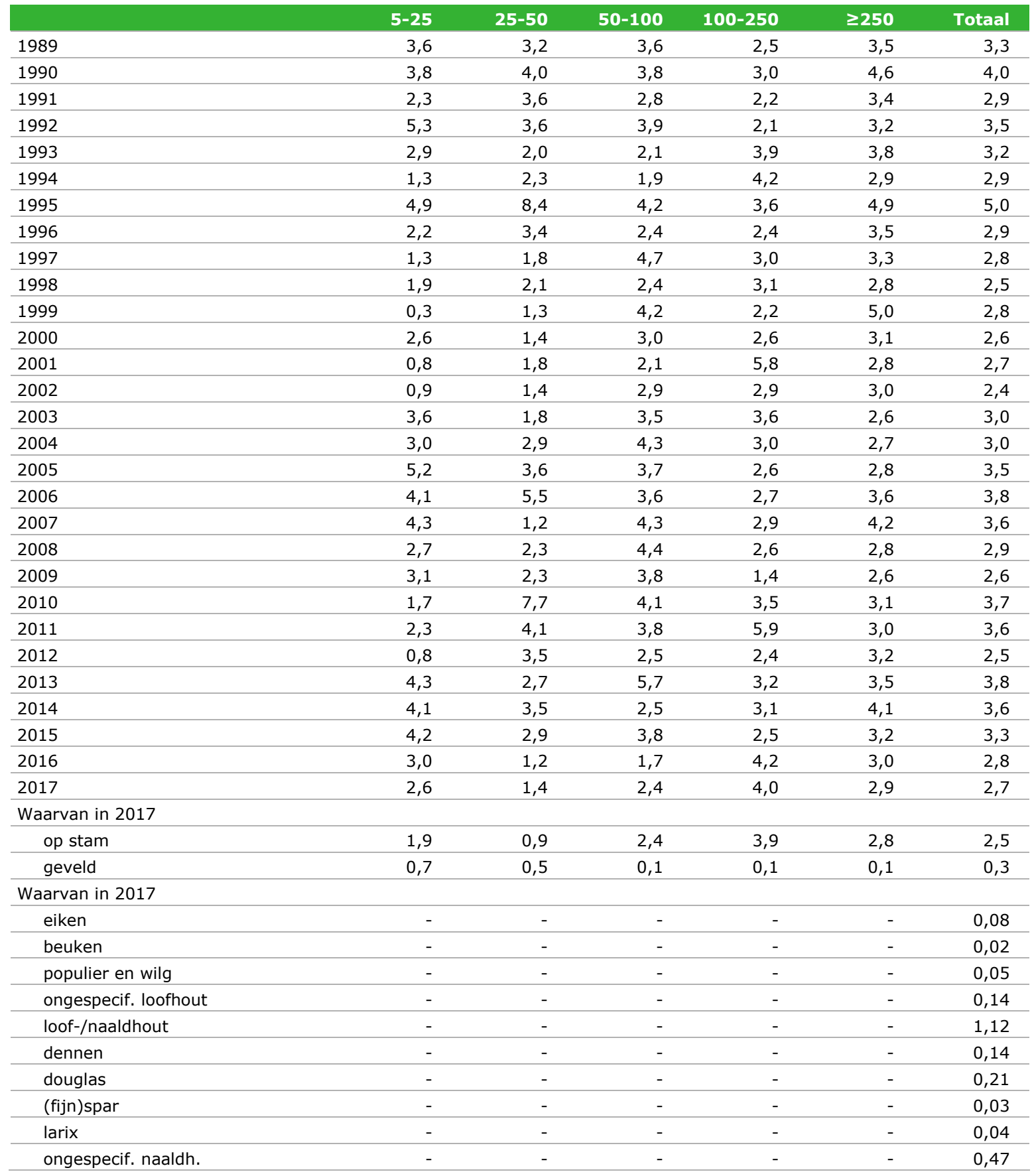


Tabel B2.13 Opbrengstprijzen (euro per $\mathrm{m}^{3}$ ) op stam en geveld verkocht hout naar regio, 1996-2017

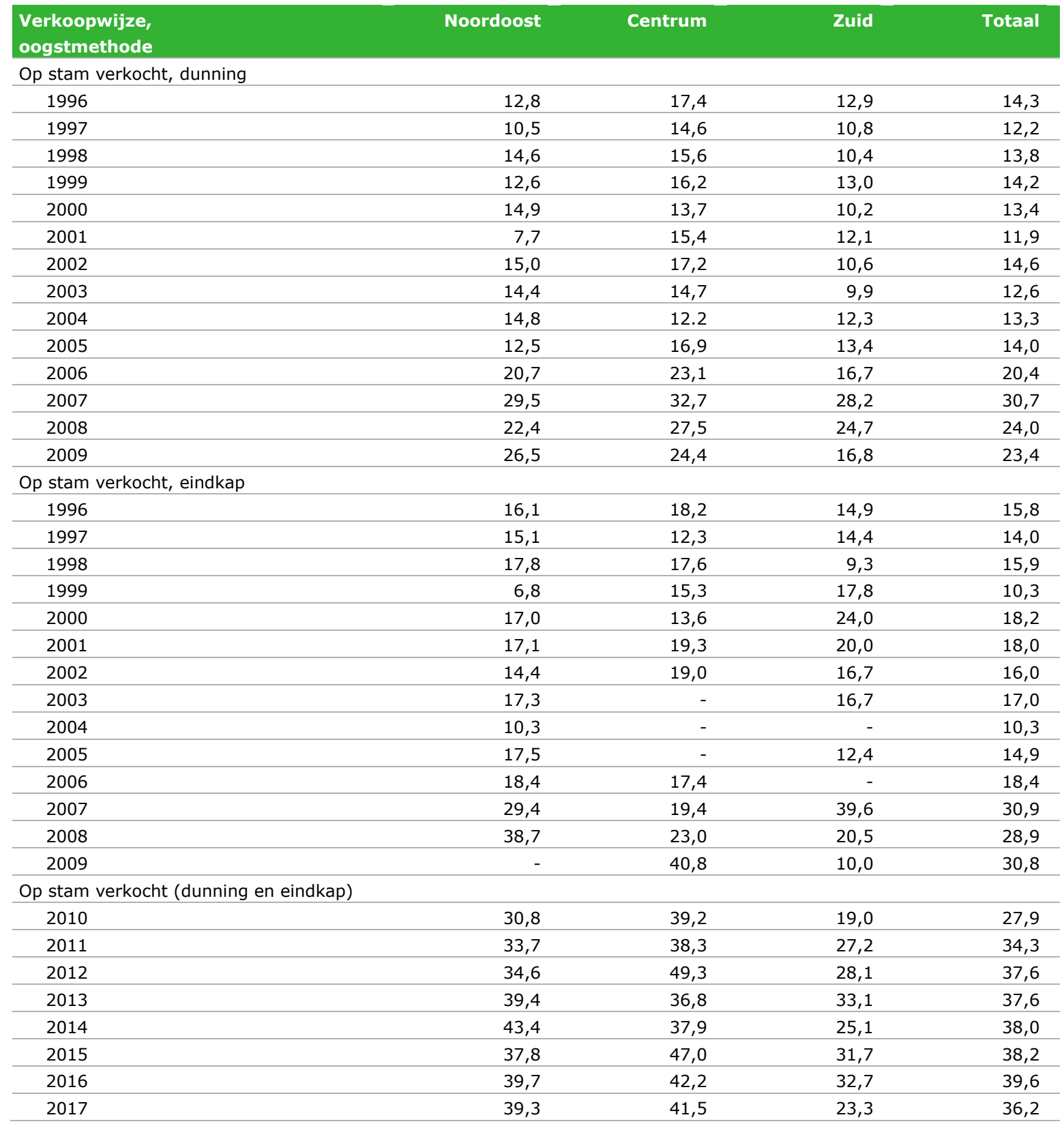


Tabel B2.13 (vervolg) Opbrengstprijzen (euro per $\mathrm{m}^{3}$ ) op stam en geveld verkocht hout naar regio, 1996-2017

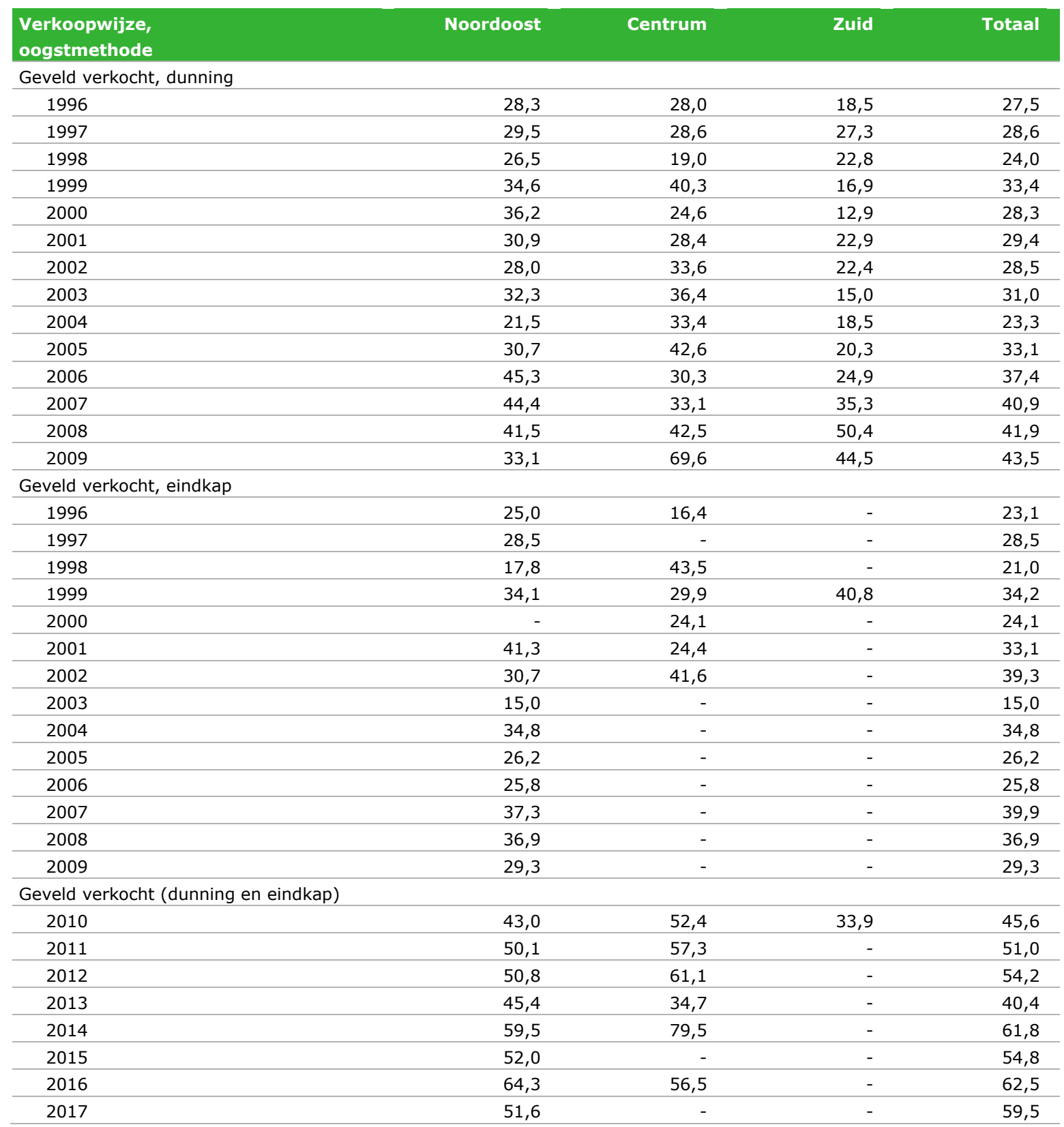


Tabel B2.14 Opbrengstprijzen (euro per $\mathrm{m}^{3}$ ) op stam en geveld verkocht hout naar omvang bosareaal in ha, 1996-2017

\begin{tabular}{|c|c|c|c|c|c|c|}
\hline $\begin{array}{l}\text { Verkoopwijze, } \\
\text { oogstmethode }\end{array}$ & $5-25$ & $25-50$ & $50-100$ & $100-250$ & $\geq 250$ & Totaal \\
\hline \multicolumn{7}{|c|}{ Op stam verkocht, dunning } \\
\hline 1997 & 5,7 & 12,3 & 11,9 & 13,9 & 13,8 & 12,2 \\
\hline 1998 & 8,0 & 16,9 & 16,1 & 10,8 & 13,9 & 13,8 \\
\hline 2001 & - & 18,6 & 17,2 & 6,0 & 15,2 & 11,9 \\
\hline 2002 & 28,4 & 13,5 & 15,3 & 13,7 & 14,7 & 14,6 \\
\hline 2003 & 8,6 & 22,0 & 11,9 & 11,6 & 13,3 & 12,6 \\
\hline 2004 & 12,1 & 23,8 & 9,2 & 11,7 & 15,6 & 13,3 \\
\hline 2009 & 15,1 & 24,1 & 26,0 & 18,3 & 27,1 & 23,4 \\
\hline \multicolumn{7}{|c|}{ Op stam verkocht, eindkap } \\
\hline 1996 & - & 15,6 & 17,1 & 13,3 & 16,2 & 15,8 \\
\hline 1997 & - & 17,6 & 15,1 & 12,2 & 13,9 & 14,0 \\
\hline 1998 & - & 19,9 & 13,3 & 16,8 & 14,6 & 15,9 \\
\hline 1999 & - & 22,0 & 13,6 & 20,2 & 6,9 & 10,3 \\
\hline 2000 & - & - & 15,3 & 28,0 & 18,9 & 18,2 \\
\hline 2001 & - & 18,2 & 16,4 & 17,4 & 19,4 & 18,0 \\
\hline 2002 & - & - & 11,9 & 11,7 & 18,3 & 16,0 \\
\hline 2009 & 10,0 & - & - & - & 40,8 & 30,8 \\
\hline \multicolumn{7}{|c|}{ Op stam verkocht (dunning en eindkap) } \\
\hline 2010 & 23,7 & 19,6 & 34,0 & 29,5 & 33,3 & 27,9 \\
\hline 2011 & 27,8 & 38,4 & 24,9 & 34,7 & 38,3 & 34,3 \\
\hline 2012 & 46,0 & 39,5 & 37,8 & 32,5 & 37,9 & 37,6 \\
\hline 2013 & 31,8 & 30,0 & 49,6 & 33,5 & 38,1 & 37,6 \\
\hline 2014 & 51,2 & 28,5 & 40,7 & 35,2 & 34,3 & 38,0 \\
\hline 2015 & 39,9 & 38,8 & 34,9 & 41,9 & 37,8 & 38,2 \\
\hline 2016 & 18,8 & 24,6 & 45,3 & 38,9 & 42,1 & 39,6 \\
\hline 2017 & 24,2 & 47,8 & 55,2 & 43,3 & 30,1 & 36,2 \\
\hline
\end{tabular}


Tabel B2.14 (vervolg) Opbrengstprijzen (euro per $\mathrm{m}^{3}$ ) op stam en geveld verkocht hout naar omvang bosareaal in ha, 1996-2017

\begin{tabular}{|c|c|c|c|c|c|c|}
\hline $\begin{array}{l}\text { Verkoopwijze, } \\
\text { oogstmethode }\end{array}$ & $5-25$ & $25-50$ & $50-100$ & $100-250$ & $\geq 250$ & Totaal \\
\hline \multicolumn{7}{|c|}{ Geveld verkocht, dunning } \\
\hline 1997 & 27,6 & 27,0 & 25,6 & 27,9 & 30,8 & 28,6 \\
\hline 1998 & 14,5 & 20,9 & 25,1 & 33,1 & 42,9 & 24,0 \\
\hline 2001 & 24,1 & 28,5 & 18,0 & 31,6 & 36,6 & 29,4 \\
\hline 2002 & 26,4 & 12,3 & 22,0 & 23,2 & 36,3 & 28,5 \\
\hline 2003 & 25,9 & 19,6 & 33,0 & 20,3 & 39,5 & 31,0 \\
\hline 2004 & 14,1 & 28,1 & 27,1 & 31,4 & 32,3 & 23,3 \\
\hline 2008 & 33,6 & 39,9 & 35,8 & 38,8 & 50,2 & 41,9 \\
\hline 2009 & 64,0 & 43,9 & 28,2 & 50,7 & 30,2 & 43,5 \\
\hline \multicolumn{7}{|c|}{ Geveld verkocht, eindkap } \\
\hline 1996 & - & 6,8 & - & 25,0 & 21,1 & 23,1 \\
\hline 1997 & - & - & 26,5 & 35,3 & 27,3 & 28,5 \\
\hline 1998 & 13,3 & - & 23,7 & 29,2 & 42,8 & 21,0 \\
\hline 1999 & - & 43,2 & - & 28,5 & 25,6 & 34,2 \\
\hline 2000 & - & - & - & - & 24,1 & 24,1 \\
\hline 2001 & - & 41,3 & - & - & 24,4 & 33,1 \\
\hline 2009 & 30,0 & - & - & 28,0 & - & 29,3 \\
\hline \multicolumn{7}{|c|}{ Geveld verkocht (dunning en eindkap) } \\
\hline 2010 & 56,4 & 67,8 & 50,0 & 34,8 & 41,0 & 45,6 \\
\hline 2011 & 56,5 & 47,8 & - & 48,2 & 34,1 & 51,0 \\
\hline 2012 & 54,1 & - & - & - & 55,1 & 54,2 \\
\hline 2013 & 53,9 & 32,3 & - & - & 41,8 & 40,4 \\
\hline 2014 & 65,6 & 46,0 & - & - & 66,7 & 61,8 \\
\hline 2015 & 60,5 & 42,8 & - & - & 51,8 & 54,8 \\
\hline 2016 & 61,5 & - & - & 53,1 & 68,7 & 62,5 \\
\hline 2017 & 83,6 & 39,6 & 57,7 & 51,0 & 64,5 & 59,5 \\
\hline
\end{tabular}


Tabel B2.15 Opbrengstprijzen (euro per $\mathrm{m}^{3}$ ) naar houtsoort en verkoopwijze, 2013-2017

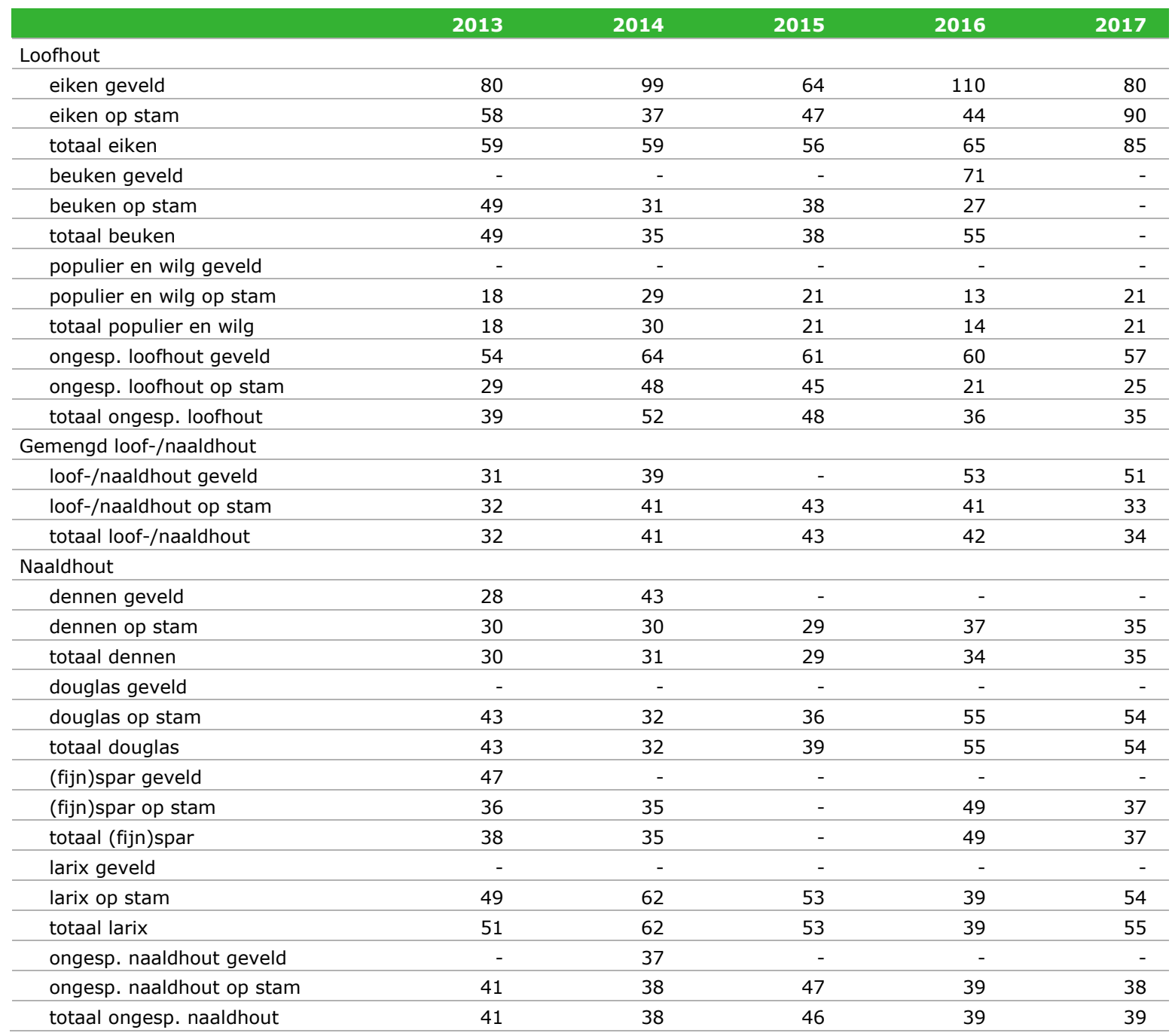


Wageningen Economic Research Postbus 29703

2502 LS Den Haag

T 0703358330

Ecommunications.ssg@wur.nl

www.wur.nl/economic-research

Wageningen Economic Research RAPPORT

2019-048
De missie van Wageningen University \& Research is 'To explore the potential of nature to improve the quality of life'. Binnen Wageningen University \& Research bundelen Wageningen University en gespecialiseerde onderzoeksinstituten van Stichting Wageningen Research hun krachten om bij te dragen aan de oplossing van belangrijke vragen in het domein van gezonde voeding en leefomgeving. Met ongeveer 30 vestigingen, 5.000 medewerkers en 10.000 studenten behoort Wageningen University \& Research wereldwijd tot de aansprekende kennisinstellingen binnen haar domein. De integrale benadering van de vraagstukken en de samenwerking tussen verschillende disciplines vormen het hart van de unieke Wageningen aanpak. 



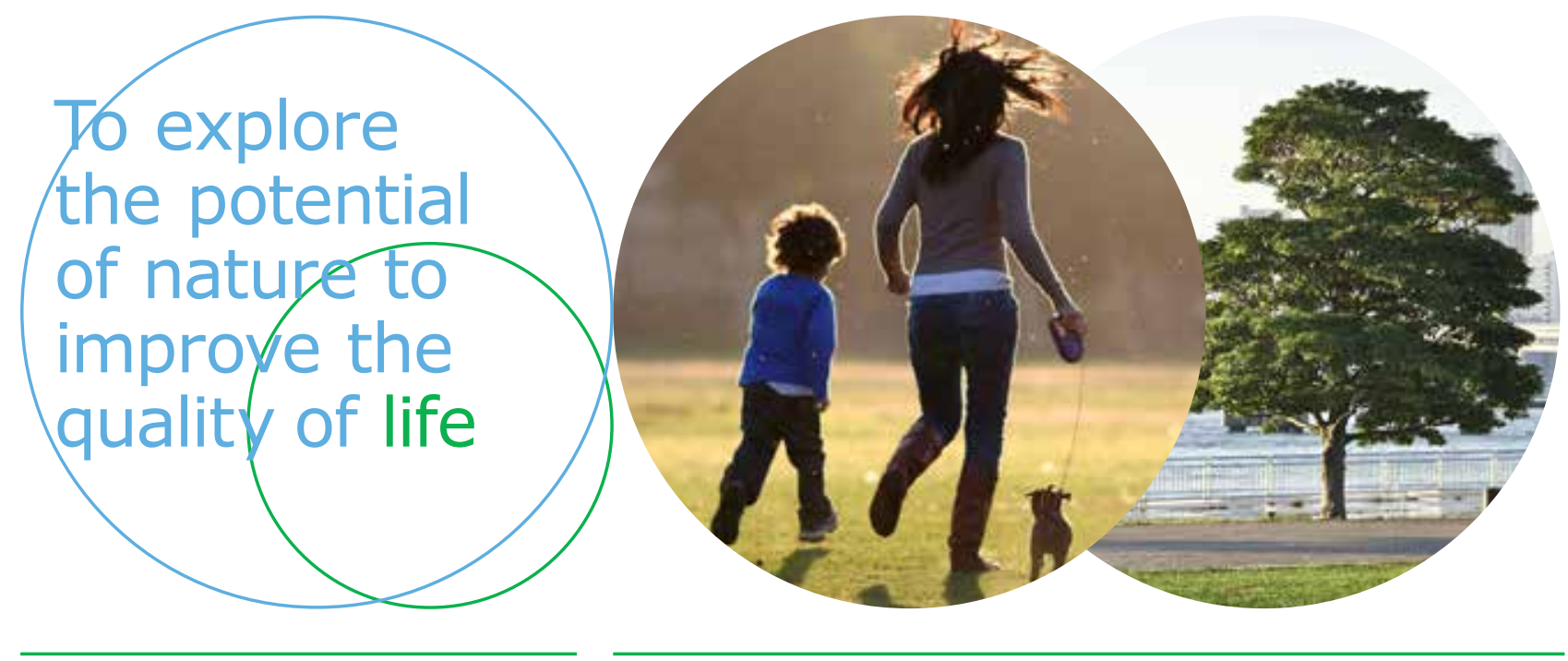

Wageningen Economic Research Postbus 29703

2502 LS Den Haag

E communications.ssg@wur.nl

$\mathrm{T}+31(0) 703358330$

www.wur.nl/economic-research

Rapport 2019.048

ISBN 978-94-6343-980-0
De missie van Wageningen University \& Research is 'To explore the potential of nature to improve the quality of life'. Binnen Wageningen University \& Research bundelen Wageningen University en gespecialiseerde onderzoeksinstituten van Stichting Wageningen Research hun krachten om bij te dragen aan de oplossing van belangrijke vragen in het domein van gezonde voeding en leefomgeving. Met ongeveer 30 vestigingen, 5.000 medewerkers en 10.000 studenten behoort Wageningen University \& Research wereldwijd tot de aansprekende kennisinstellingen binnen haar domein. De integrale benadering van de vraagstukken en de samenwerking tussen verschillende disciplines vormen het hart van de unieke Wageningen aanpak. 